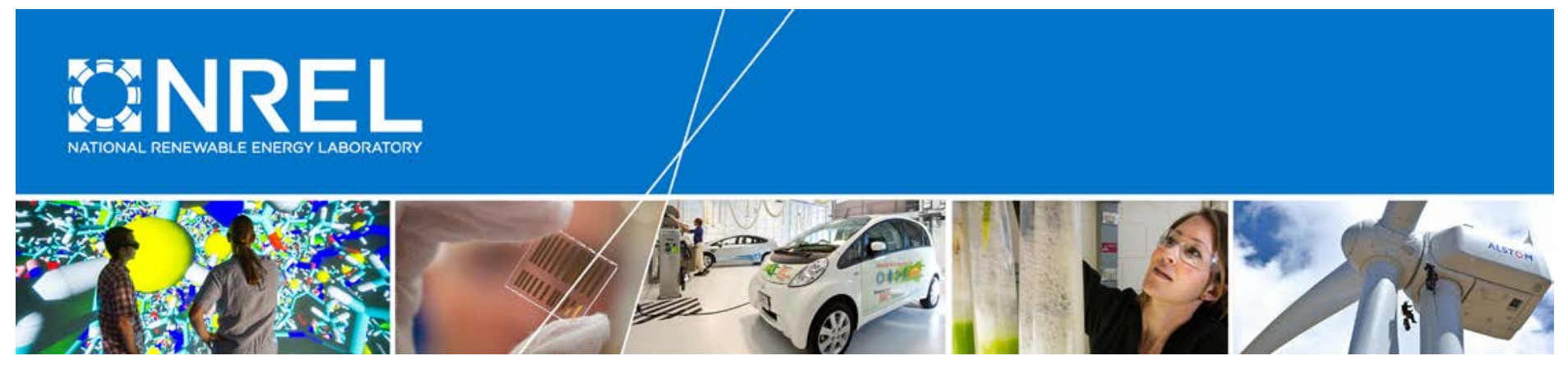

\title{
Fuel Cell Buses in U.S. Transit Fleets: \\ Current Status 2015
}

Leslie Eudy and Matthew Post

National Renewable Energy Laboratory

Christina Gikakis

Federal Transit Administration

NREL is a national laboratory of the U.S. Department of Energy Office of Energy Efficiency \& Renewable Energy

Operated by the Alliance for Sustainable Energy, LLC

This report is available at no cost from the National Renewable Energy Laboratory (NREL) at www.nrel.gov/publications.

Technical Report

NREL/TP-5400-64974

December 2015

Contract No. DE-AC36-08GO28308 


\section{Fuel Cell Buses in U.S. Transit Fleets: Current Status 2015}

Leslie Eudy and Matthew Post

National Renewable Energy Laboratory

Christina Gikakis

Federal Transit Administration

Prepared under Task No. HT12.8210
NREL is a national laboratory of the U.S. Department of Energy Office of Energy Efficiency \& Renewable Energy Operated by the Alliance for Sustainable Energy, LLC

This report is available at no cost from the National Renewable Energy Laboratory (NREL) at www.nrel.gov/publications.

\section{Technical Report}

NREL/TP-5400-64974

December 2015

Contract No. DE-AC36-08GO28308
15013 Denver West Parkway

Golden, CO 80401

303-275-3000 • www.nrel.gov 


\section{NOTICE}

This report was prepared as an account of work sponsored by an agency of the United States government. Neither the United States government nor any agency thereof, nor any of their employees, makes any warranty, express or implied, or assumes any legal liability or responsibility for the accuracy, completeness, or usefulness of any information, apparatus, product, or process disclosed, or represents that its use would not infringe privately owned rights. Reference herein to any specific commercial product, process, or service by trade name, trademark, manufacturer, or otherwise does not necessarily constitute or imply its endorsement, recommendation, or favoring by the United States government or any agency thereof. The views and opinions of authors expressed herein do not necessarily state or reflect those of the United States government or any agency thereof.

This report is available at no cost from the National Renewable Energy Laboratory (NREL) at www.nrel.gov/publications.

Available electronically at SciTech Connect http:/www.osti.gov/scitech

Available for a processing fee to U.S. Department of Energy and its contractors, in paper, from:

U.S. Department of Energy

Office of Scientific and Technical Information

P.O. Box 62

Oak Ridge, TN 37831-0062

OSTI http://www.osti.gov

Phone: 865.576.8401

Fax: 865.576.5728

Email: reports@osti.gov

Available for sale to the public, in paper, from:

U.S. Department of Commerce

National Technical Information Service

5301 Shawnee Road

Alexandria, VA 22312

NTIS http://www.ntis.gov

Phone: 800.553 .6847 or 703.605 .6000

Fax: 703.605.6900

Email: orders@ntis.gov 


\section{Acknowledgments}

This document includes results and experiences from several U.S. fuel cell electric bus evaluation projects. The active participation of our project partners is greatly appreciated. Contributors to this report included staff members of federal and state government agencies, manufacturing firms, and transit authorities. The authors especially thank the following individuals:

Salvador Llamas, Roland Fecteau, Chris Durant, and Jose Vega, Alameda-Contra Costa Transit District

Tommy Edwards, Polo Del Toro, and Mike Hayes, SunLine Transit Agency

Steve Miller, Golden Gate Transit

Jason Marcinkoski, U.S. Department of Energy

Sean Ricketson, U.S. Department of Transportation, Federal Transit Administration

Abas Goodarzi and Reza Sarhadi, US Hybrid

Byron Somerville and Jeff Grant, Ballard Power Systems

Robert Devine and Yesh Premkumar, BAE Systems

Nico Bouwkamp, California Fuel Cell Partnership

Erik Bigelow and Jaimie Levin, Center for Transportation and the Environment

Keith Wipke and Jen Kurtz, National Renewable Energy Laboratory

Unless otherwise noted, photo credit for all pictures in the report: L. Eudy, NREL 


\section{Acronyms and Abbreviations}

AC Transit

AFCB

$\mathrm{AT}$

BJCTA

$\mathrm{CNG}$

CTE

CTTRANSIT

DGE

DOE

FC

FCEB

FCPP

$\mathrm{ft}$

FTA

GGE

$\mathrm{kg}$

MBRC

mph

NAVC

NFCBP

NREL

OEM

TIGGER

TRL

ZEBA
Alameda-Contra Costa Transit District

American Fuel Cell Bus

advanced technology

Birmingham-Jefferson County Transit Authority

compressed natural gas

Center for Transportation and the Environment

Connecticut Transit

diesel gallon equivalent

U.S. Department of Energy

fuel cell

fuel cell electric bus

fuel cell power plant

feet

Federal Transit Administration

gasoline gallon equivalent

kilograms

miles between roadcalls

miles per hour

Northeast Advanced Vehicle Consortium

National Fuel Cell Bus Program

National Renewable Energy Laboratory

original equipment manufacturer

Transit Investments for Greenhouse Gas and Energy

Reduction

technology readiness level

Zero Emission Bay Area 


\section{Definition of Terms}

Availability: The number of days the buses are actually available compared to the days that the buses are planned for operation expressed as percent availability.

Balance of plant: The components of the fuel cell system — such as air compressor, fans, and pumps - that support the operation of the fuel cell stack.

Clean point: The starting point for the data analysis period. For each evaluation, NREL works with the project partners to determine a starting point — or clean point — for the data analysis period. The clean point is chosen to avoid some of the early and expected operations problems with a new vehicle going into service, such as early maintenance campaigns. In some cases, reaching the clean point may require 3 to 6 months of operation before the evaluation can start.

Fast-fill: Per the SAE International J2601/2 standard, a flow rate of 61 to 120 grams per second is considered a fast-fill. Transit agencies have a goal of completing a full fill of a hydrogenfueled bus in 10 minutes or less.

Miles between roadcalls (MBRC): A measure of reliability calculated by dividing the number of miles traveled by the number of roadcalls. (Also known as mean distance between failures.) $\mathrm{MBRC}$ results in the report are categorized as follows:

- Bus MBRC: Includes all chargeable roadcalls. Includes propulsion-related issues as well as problems with bus-related systems such as brakes, suspension, steering, windows, doors, and tires.

- Propulsion-related MBRC: Includes roadcalls that are attributed to the propulsion system. Propulsion-related roadcalls can be caused by issues with the power system (fuel cell), batteries, and hybrid systems.

- Fuel-cell-system-related MBRC: Includes roadcalls attributed to the fuel cell power plant and balance of plant only.

Revenue service: The time when a vehicle is available to the general public with an expectation of carrying fare-paying passengers. Vehicles operated in a fare-free service are also considered revenue service.

Roadcall: A failure of an in-service bus that causes the bus to be replaced on route or causes a significant delay in schedule. The analysis includes chargeable roadcalls that affect the operation of the bus or may cause a safety hazard. Non-chargeable roadcalls can be passenger incidents that require the bus to be cleaned before going back into service or problems with an accessory such as a farebox or radio. 


\section{Executive Summary}

This report, published annually, summarizes the progress of fuel cell electric bus (FCEB) development in the United States and discusses the achievements and challenges of introducing fuel cell propulsion in transit. The report provides a summary of results from evaluations performed by the National Renewable Energy Laboratory (NREL). Funding for this effort is provided by the U.S. Department of Energy's (DOE's) Fuel Cell Technologies Office within the Office of Energy Efficiency and Renewable Energy and by the U.S. Department of Transportation's Federal Transit Administration (FTA).

NREL publishes individual reports on each demonstration that focus on the results and experiences for that specific project. The annual status report combines results from all of those FCEB demonstrations, tracks the progress of the FCEB industry toward meeting technical targets (as shown in Table ES-1), documents the lessons learned, and discusses the path forward for commercial viability of fuel cell technology for transit buses. Its intent is to inform FTA and DOE decision makers who direct research and funding; state and local government agencies that fund new propulsion technology transit buses; and interested transit agencies and industry manufacturers.

The 2015 summary results primarily focus on the most recent year for each demonstration, from August 2014 through July 2015. The results for these buses account for more than 1,045,000 miles traveled and 83,000 hours of fuel cell power system operation. The primary results presented in the report are from two demonstrations of fuel-cell-dominant bus designs:

- Zero Emission Bay Area Demonstration Group led by Alameda-Contra Costa Transit District (AC Transit) in California

- American Fuel Cell Bus Project at SunLine Transit Agency in California.

At this point in the development, FCEBs are not commercial products. NREL considers these FCEB designs to be around technology readiness level (TRL) 7, that is, full-scale validation in a relevant environment. The manufacturers' goals for these demonstrations are to verify that the FCEB performance meets the technical targets and identify any issues that need to be resolved. The current costs for FCEB technology — both capital and operating costs - are still much higher than the costs of conventional diesel and compressed natural gas technologies. This is expected considering diesel and compressed natural gas are very mature technologies (TRL 9).

NREL also collected data on two prototype FCEBs that are considered to be around TRL 6. These demonstrations began in 2014. As early-generation prototypes, these designs are in the early stages of demonstration and evaluation. During this stage, the manufacturers are enlisting the help of transit agencies to conduct field tests and shakedown of the design in a real world environment. NREL has collected a limited set of data on the buses.

NREL collected and analyzed conventional baseline bus data from each site for comparison with the FCEB data. At AC Transit, the baseline buses are diesel buses. The baseline buses at SunLine are compressed natural gas buses because the agency does not operate diesel buses. The baseline buses are selected to be as close a match to the FCEBs as possible and operated in similar service. 
DOE and FTA have established performance and cost targets for FCEBs. These targets, established with industry input, include interim targets for 2016 and ultimate targets for commercialization. FCEB technology continues to show progress toward meeting technical targets for increasing reliability and durability while also reducing costs. Table ES- 1 summarizes the performance of the FCEBs in the report compared to these targets.

Table ES-1. Summary of FCEB Performance Compared to DOE/FTA Targets ${ }^{1}$

\begin{tabular}{|c|c|c|c|c|}
\hline & Units & $\begin{array}{l}\text { Current Status }{ }^{a} \\
\text { (Range) }\end{array}$ & $\begin{array}{c}2016 \\
\text { Target }^{1}\end{array}$ & $\begin{array}{l}\text { Ultimate } \\
\text { Target }^{1}\end{array}$ \\
\hline Bus lifetime & years/miles & $\begin{array}{c}0.25-4.9 / \\
7,900-117,000^{\mathrm{b}}\end{array}$ & $12 / 500,000$ & $12 / 500,000$ \\
\hline Power plant lifetime $^{c}$ & hours & $660-20,000^{\mathrm{b}, \mathrm{d}, \mathrm{e}}$ & 18,000 & 25,000 \\
\hline Bus availability & $\%$ & $40-92$ & 85 & 90 \\
\hline Fuel fills $^{f}$ & per day & 1 & $1(<10 \mathrm{~min})$ & 1 (<10 min) \\
\hline Bus cost ${ }^{g}$ & $\$$ & $\begin{array}{c}2,100,000- \\
2,400,000\end{array}$ & $1,000,000$ & 600,000 \\
\hline $\begin{array}{l}\text { Roadcall frequency } \\
\text { (bus/fuel cell system) }\end{array}$ & $\begin{array}{l}\text { miles between } \\
\text { roadcalls }\end{array}$ & $\begin{array}{c}1,800-6,800 / \\
9,000-104,000\end{array}$ & $\begin{array}{l}3,500 / \\
15,000\end{array}$ & $\begin{array}{l}4,000 / \\
20,000 \\
\end{array}$ \\
\hline Operation time & $\begin{array}{c}\text { hours per } \\
\text { day/days per } \\
\text { week }\end{array}$ & $\begin{array}{c}7-21 / \\
5-7\end{array}$ & $20 / 7$ & $20 / 7$ \\
\hline $\begin{array}{l}\text { Scheduled and } \\
\text { unscheduled } \\
\text { maintenance cost }\end{array}$ & \$/mile & $0.54-1.33$ & 0.75 & 0.40 \\
\hline Range & miles & $240-340^{i}$ & 300 & 300 \\
\hline Fuel economy & $\begin{array}{l}\text { miles per diesel } \\
\text { gallon equivalent }\end{array}$ & $5.56-7.71$ & 8 & 8 \\
\hline
\end{tabular}

${ }^{a}$ The summary of results in this report represents a snapshot from the included demonstrations: data from August 2014 to July 2015.

${ }^{\mathrm{b}}$ Accumulated totals for existing fleet through July 2015; these buses have not reached end of life.

${ }^{c}$ For the DOE/FTA targets, the power plant is defined as the fuel cell system and the battery system. The fuel cell system includes supporting subsystems such as the air, fuel, coolant, and control subsystems. Power electronics, electric drive, and hydrogen storage tanks are excluded.

${ }^{\mathrm{d}}$ The status for power plant hours is for the fuel cell system only; battery lifetime hours were not available.

${ }^{\mathrm{e}}$ The highest-hour power plant was transferred from an older-generation bus that had accumulated more than 6,000 hours prior to transfer.

${ }^{\mathrm{f}}$ Multiple sequential fuel fills should be possible without an increase in fill time.

${ }^{\mathrm{g}}$ Cost targets are projected to a production volume of 400 systems per year. This production volume is assumed for analysis purposes only and does not represent an anticipated level of sales.

${ }^{\text {h }}$ Excludes mid-life overhaul of power plant.

${ }^{\mathrm{i}}$ Based on fuel economy and $95 \%$ tank capacity.

DOE/FTA set an ultimate performance target of 4-6 years (or 25,000 hours) durability for the fuel cell propulsion system, with an interim target of 18,000 hours by 2016. Over the last year, manufacturers made significant progress toward meeting the target. At the end of the analysis period for this report (July 2015), NREL documented a single fuel cell power plant that had

\footnotetext{
${ }^{1}$ Fuel Cell Technologies Program Record \# 12012, September 12, 2012, www.hydrogen.energy.gov/pdfs/12012_fuel_cell_bus_targets.pdf.
} 
reached 20,000 hours, exceeding the 2016 target. Of the 16 fuel cell power plants included in the data set, $75 \%$ (12) have surpassed 10,000 hours of operation. The average hours accumulated is 10,102 .

Availability continues to vary from site to site with per-bus data from the last year ranging from a low of $40 \%$ to a high of $92 \%$, with the overall average at $74 \%$. This is slightly higher than what was reported last year (70\% average availability). Many of the issues are attributed to bus-related problems such as windshields and cooling pumps. In the last year, both agencies have seen an increase in issues related to the hybrid system, batteries, and fuel cell systems. Downtime has been extended in some cases because intermittent issues are difficult to troubleshoot.

The targets for roadcall frequency include miles between roadcalls (MBRC) for the entire bus and MBRC for the fuel cell system only. The fuel cell system MBRC includes any roadcalls due to issues with the fuel cell stack or associated balance of plant. The overall MBRC was 4,280 MBRC for the bus and 20,885 MBRC for the fuel cell system. Bus MBRC shows a general upward trend, surpassing the 2016 target and the ultimate target at the end of the data period. Fuel cell system MBRC shows a steady upward trend over time, also surpassing the ultimate target.

The FCEBs continue to show higher fuel economy compared to the baseline buses in similar service. FTA's performance target for FCEB fuel economy is 8 miles per diesel gallon equivalent (DGE), which is approximately 2 times higher than that of typical conventional diesel buses. Actual data from the FCEBs included in this report showed fuel economy ranging from 1.6 to 1.73 times higher than that of diesel baseline buses (AC Transit) and 1.95 times higher than that of compressed natural gas baseline buses (SunLine). The average fuel economy for the FCEBs over the last year was 5.8 miles per DGE.

FCEB performance continues to improve; however, there are still challenges to overcome to make the technology commercially viable. Challenges include the following:

- Integration and optimization of components. Issues with systems integration and optimization continue to be a challenge for FCEBs. Transit agencies are working closely with the manufacturers to diagnose and address issues to eliminate problems and increase performance. New diagnostic tools have helped, but the agencies are still experiencing problems that are difficult to diagnose and result in extended downtimes.

- Transition of maintenance to transit staff. The transition of knowledge from the manufacturers to the transit staff is essential to commercializing the technology. SunLine's staff has been handling the majority of maintenance tasks for several years. This agency's transition was faster because of its past FCEB experience dating back to 2000. Over the last year, AC transit has successfully transitioned the maintenance to onsite staff. The agency has trained more personnel to cover the FCEB fleet. The agency has access to the service and maintenance manual, wireless diagnostic tools, and other resources to help troubleshoot issues and perform the repairs on-site.

- Integrating FCEB designs into the standard bus build process. For FCEBs to be fully commercialized, the fuel cell hybrid propulsion system needs to be an option offered by the bus original equipment manufacturer, as is the case with other propulsion systems. 
The development team of BAE Systems, Ballard, and ElDorado National are now fielding orders for a number of American Fuel Cell Buses that are all being built at the ElDorado facility in the standard production line along with conventional-technology buses. Over the last year, New Flyer announced plans to develop a next-generation FCEB for the market. New Flyer already has a battery-electric 40 -foot bus in testing at several transit agencies. The FCEB design will be based on the battery-electric version. Both designs are built on New Flyer's Xcelsior platform, which is available with a diesel, compressed natural gas, and hybrid electric propulsion system. All of these bus designs will share many components and parts, which will help address a number of past issues experienced by FCEB demonstrations.

- Costs for FCEBs. Maintenance costs for advanced-technology buses typically start low because the buses are under warranty and begin to increase as transit staff takes on more of the maintenance responsibilities. As staff becomes more proficient, the costs eventually stabilize. The uncertainty for FCEBs at this point in development is how the parts costs will affect the overall maintenance costs over time once all of the buses are out of warranty. To help with future planning, transit agencies need to understand future costs as the technology moves into early commercial deployment. Manufacturers need to work on standardization and manufacturing processes to help lower costs for advancedtechnology parts and components.

NREL plans to continue monitoring and evaluating the demonstrations at AC Transit and SunLine. In the next year, several more FCEBs and operating sites are expected to begin demonstration; these will be included in next year's status report. 


\section{Table of Contents}

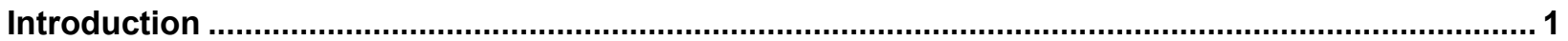

Scope and Purpose

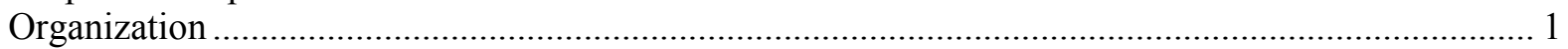

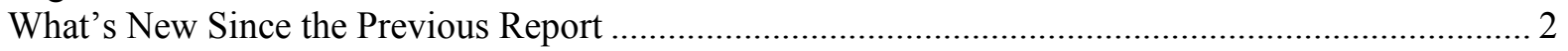

Fuel Cell Electric Buses in Operation in the United States ......................................................... 3

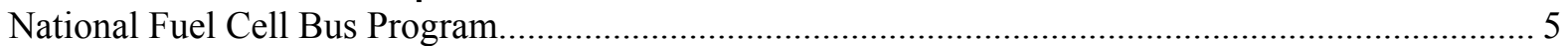

FCEB Development Process - Technology Readiness Levels …................................................... 7

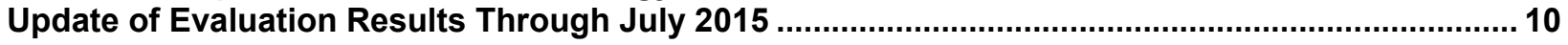

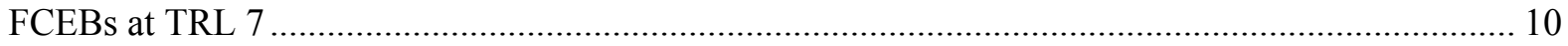

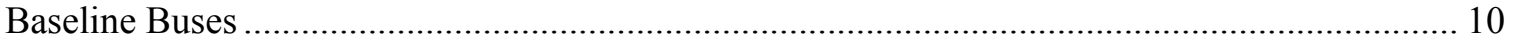

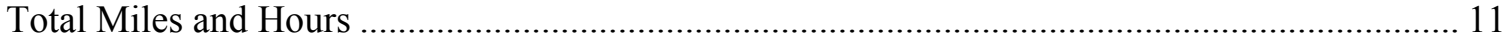

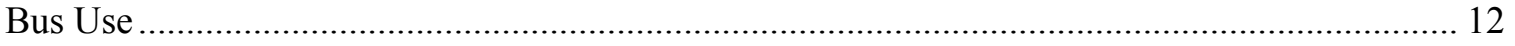

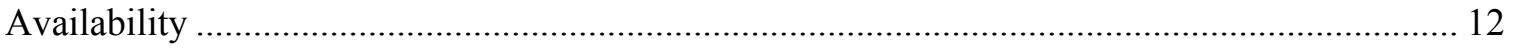

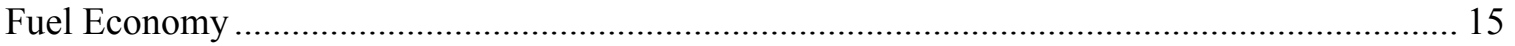

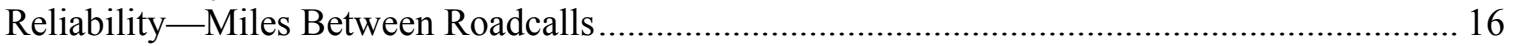

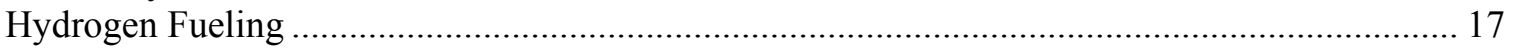

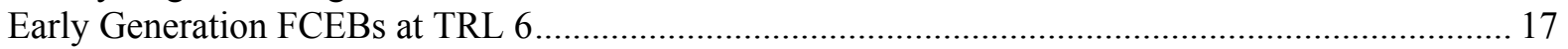

Current Status of FCEB Introductions: Summary of Achievements and Challenges ......................20

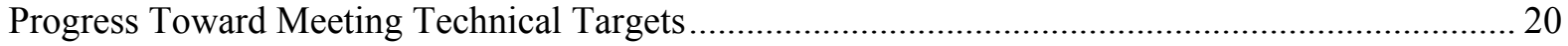

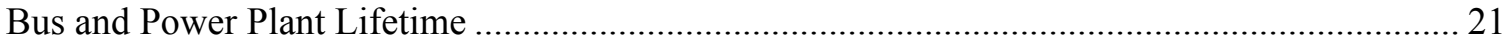

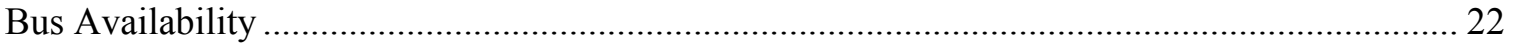

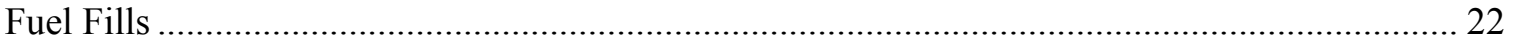

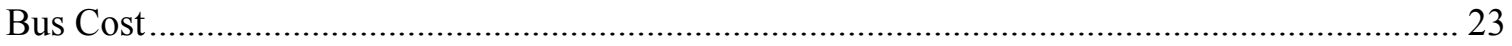

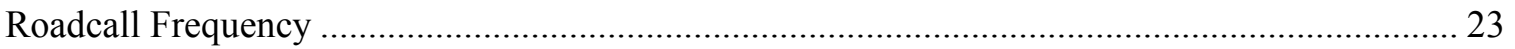

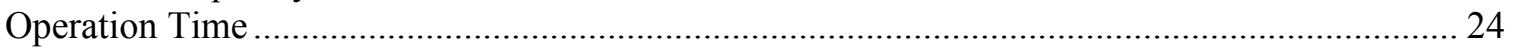

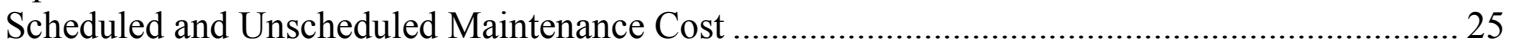

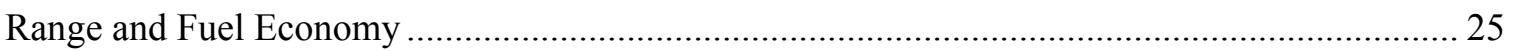

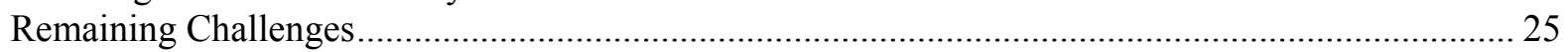

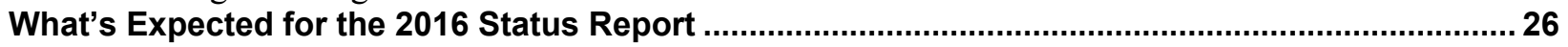

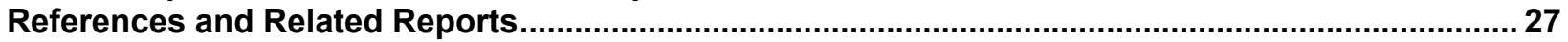

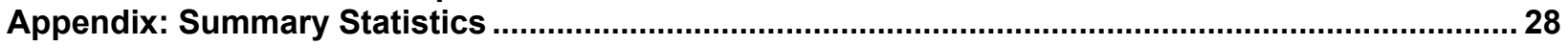

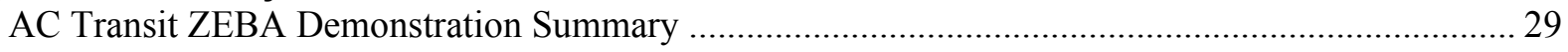

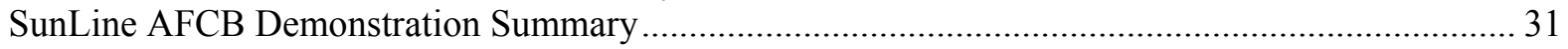




\section{Introduction}

This report is the ninth in a series of annual status reports from the U.S. Department of Energy's (DOE's) National Renewable Energy Laboratory (NREL). ${ }^{2}$ It summarizes status and progress from demonstrations of fuel cell transit buses in the United States. Since 2000, NREL has evaluated fuel cell electric bus (FCEB) demonstrations at transit agencies, looking at the buses, infrastructure, and each transit agency's implementation experience. These evaluations have been funded by DOE, the U.S. Department of Transportation's Federal Transit Administration (FTA), and the California Air Resources Board. This work is described in a joint evaluation plan. $^{3}$

\section{Scope and Purpose}

This annual status report discusses the achievements and challenges of fuel cell propulsion for transit and summarizes the introduction of fuel cell transit buses in the United States. It provides an analysis of the combined results from fuel cell transit bus demonstrations evaluated by NREL with a focus on the most recent data (through July 2015). NREL also evaluates the operating experience and costs of these demonstrations individually and posts reports at http://www.nrel.gov/hydrogen/proj_fc bus_eval.html.

This report combines results for FCEB demonstrations across the United States and discusses the path forward for commercial viability of fuel cell technology for transit buses. Its intent is to inform FTA and DOE decision makers who direct research and funding; state and local government agencies that fund new propulsion technology transit buses; and interested transit agencies and industry manufacturers.

\section{Organization}

This report is organized into six sections, beginning with this "Introduction." The section "Fuel Cell Electric Buses in Operation in North America" summarizes existing and upcoming demonstrations in the United States and Canada and includes an overview of FTA's National Fuel Cell Bus Program (NFCBP). The section "FCEB Development Process-Technology Readiness Levels" outlines the steps for developing and commercializing FCEBs and indicates where each of the current designs falls in the process. The section "Update of Evaluation Results Through July 2015" presents the results of the most recent NREL evaluations of fuel cell transit bus demonstrations with comparisons for availability, fuel economy, and roadcalls. The section "Current Status of Fuel Cell Bus Introductions: Summary of Achievements and Challenges" discusses the status and challenges of fuel cell propulsion for transit. The final section, "What's Expected for the 2016 Report," looks ahead to the results to be presented in next year's assessment report.

Additionally, the "References" section of this report lists the most recent reports, each of which documents the performance and provides an unbiased assessment of a transit agency's experience implementing FCEBs into its operation. The "Appendix" provides summary fuel cell bus data from each of the transit agencies.

\footnotetext{
${ }^{2}$ Previous reports are listed in the References section of this report.

${ }^{3}$ Fuel Cell Transit Bus Evaluations, Joint Evaluation Plan for the U.S. Department of Energy and the Federal Transit Administration, 2010, NREL/TP-560-49342.
} 


\section{What's New Since the Previous Report}

Table 1 outlines which FCEB designs were included in the 2014 and 2015 (current) status reports. The 2014 report presented the results from four FCEB demonstration projects featuring fuel-cell-dominant designs. For this report, results are updated for two of those demonstrationsthe Alameda-Contra Costa Transit District (AC Transit) Zero Emission Bay Area (ZEBA) demonstration and the American Fuel Cell Bus (AFCB) demonstration at SunLine. NREL began collecting data on two more projects in 2014: a Proterra FCEB in operation at Capital Metro in Austin, Texas, and an EVAmerica FCEB in operation at Birmingham-Jefferson County Transit Authority (BJCTA) in Birmingham, Alabama. Both these FCEBs have battery-dominant fuel cell propulsion systems.

Table 1. Technologies Included in the 2014 or 2015 Status Reports

\begin{tabular}{|l|c|c|c|}
\hline FCEB Demonstration & $\begin{array}{c}\text { Included in } \\
2014 \\
\text { Report }\end{array}$ & $\begin{array}{c}\text { Included in } \\
\text { Current } \\
\text { Report }\end{array}$ & $\begin{array}{c}\text { Status } \\
\text { (as of 7/31/15) }\end{array}$ \\
\hline AC Transit ZEBA & & & Active \\
\hline SunLine AT FCEB & & & $\begin{array}{c}\text { Active (NREL data } \\
\text { collection ended) }\end{array}$ \\
\hline SunLine AFCB & & & Active \\
\hline Proterra, Austin, Texas & & & Active \\
\hline BJCTA, Birmingham, AL & & & $\begin{array}{c}\text { Active } \\
\text { ended (3/2014) }\end{array}$ \\
\hline BC Transit & & & \\
\hline
\end{tabular}




\section{Fuel Cell Electric Buses in Operation in the United States}

Table 2 lists current FCEB demonstrations in the United States. These demonstrations focus on identifying improvements to optimize reliability and durability. As of August 2015, 24 FCEBs were active in demonstrations at several locations throughout the country.

Table 2. Current Fuel Cell Transit Bus Demonstrations in the United States ${ }^{a}$

\begin{tabular}{|c|c|c|c|c|c|}
\hline & Bus Operator & Location & $\begin{array}{l}\text { Total } \\
\text { Buses }\end{array}$ & $\begin{array}{l}\text { Active } \\
\text { Buses }^{b} \\
\end{array}$ & Technology Description \\
\hline 1 & AC Transit, ZEBA & $\begin{array}{l}\text { San Francisco } \\
\text { Bay Area, CA }\end{array}$ & 13 & 12 & $\begin{array}{l}\text { Van Hool bus and hybrid system } \\
\text { integration, US Hybrid fuel cell }\end{array}$ \\
\hline 2 & $\begin{array}{l}\text { SunLine Transit } \\
\text { Agency, AT FCEB }\end{array}$ & $\begin{array}{l}\text { Thousand } \\
\text { Palms, CA }\end{array}$ & 1 & 1 & $\begin{array}{l}\text { New Flyer bus with Bluways hybrid } \\
\text { system and Ballard fuel cell }\end{array}$ \\
\hline 3 & $\begin{array}{l}\text { SunLine Transit } \\
\text { Agency, AFCB } \\
\text { (prototype) }\end{array}$ & $\begin{array}{l}\text { Thousand } \\
\text { Palms, CA }\end{array}$ & 1 & 1 & $\begin{array}{l}\text { EIDorado/BAE Systems/Ballard next- } \\
\text { generation advanced design to meet } \\
\text { 'Buy America' requirements }\end{array}$ \\
\hline 4 & $\begin{array}{l}\text { SunLine Transit } \\
\text { Agency, AFCB }\end{array}$ & $\begin{array}{l}\text { Thousand } \\
\text { Palms, CA }\end{array}$ & 3 & 3 & $\begin{array}{l}\text { EIDorado/BAE Systems/Ballard } \\
\text { updated AFCB design }\end{array}$ \\
\hline 5 & BJCTA & Birmingham, AL & 1 & 1 & $\begin{array}{l}\text { EVAmerica bus with Embedded } \\
\text { Power hybrid system and Ballard fuel } \\
\text { cell }\end{array}$ \\
\hline 6 & Capital Metro & Austin, TX & 1 & 1 & $\begin{array}{l}\text { Proterra composite body with a next- } \\
\text { generation battery-dominant hybrid } \\
\text { system and a Hydrogenics fuel cell }\end{array}$ \\
\hline 7 & $\begin{array}{l}\text { University of } \\
\text { California at Irvine }\end{array}$ & Irvine, CA & 1 & 1 & $\begin{array}{l}\text { EIDorado/BAE Systems/Ballard } \\
\text { updated AFCB design }\end{array}$ \\
\hline 8 & $\begin{array}{l}\text { Flint MTA, } \\
\text { Nutmeg }\end{array}$ & Flint, MI & 1 & 1 & $\begin{array}{l}\text { Van Hool bus and hybrid system } \\
\text { integration, US Hybrid fuel cell }\end{array}$ \\
\hline 9 & Flint MTA, AFCB & Flint, MI & 1 & 1 & $\begin{array}{l}\text { EIDorado/BAE Systems/Ballard } \\
\text { updated AFCB design }\end{array}$ \\
\hline 10 & $\begin{array}{l}\text { University of } \\
\text { Delaware } \\
\text { (Phase } 1 \text { and 2) }\end{array}$ & Newark, DE & 2 & 1 & $\begin{array}{l}\text { Ebus battery-dominant plug-in hybrid } \\
\text { using Ballard fuel cells ( } 22-\mathrm{ft})\end{array}$ \\
\hline 11 & $\begin{array}{l}\text { Greater New } \\
\text { Haven Transit } \\
\text { District }\end{array}$ & New Haven, CT & 1 & 1 & $\begin{array}{l}\text { Ebus battery-dominant plug-in hybrid } \\
\text { using Ballard fuel cells ( } 22-\mathrm{ft})\end{array}$ \\
\hline & & Total & 26 & 24 & \\
\hline
\end{tabular}

${ }^{a}$ Blue shaded rows indicate the project received funding through the NFCBP.

${ }^{\mathrm{b}}$ Total buses in actual service as of August 2015.

NREL has evaluated the first seven demonstrations shown in Table 2. The demonstrations, along with the current status, are described in more detail below.

- ZEBA Demonstration Group led by AC Transit-Demonstration of 13 nextgeneration Van Hool fuel cell hybrid buses with a fuel cell system by US Hybrid. NREL completed four reports on the demonstration (in August 2011, July 2012, May 2014, and July 2015). Four additional buses of this design were demonstrated in Connecticut as part of the NFCBP Nutmeg project. That project has concluded and one of those four buses 
was transferred to AC Transit, bringing the fleet to 13 FCEBs. AC Transit was awarded additional NFCBP funds to provide continued manufacturer support for the in-service demonstration through 2016.

- SunLine Transit Agency: Advanced Technology (AT) FCEB-Demonstration of one New Flyer bus with a hybrid system using a Ballard fuel cell. This bus went into service in May 2010. NREL completed four reports on this bus (in March 2011, October 2011, May 2012, and January 2013). This bus was the pilot bus for the BC Transit fleet operated in Whistler, Canada, from February 2010 through March 2014. NREL has completed the evaluation on this bus and does not plan additional reports.

- SunLine Transit Agency: AFCB Project (prototype)-Demonstration of one ElDorado National bus with a BAE Systems hybrid propulsion system and a Ballard fuel cell power system. This prototype bus was developed under funding through the NFCBP. NREL began data collection in December 2011 and the first report was completed in June 2013. NREL published a second report in September 2015.

- SunLine Transit Agency: AFCB Project-Demonstration of three AFCBs (ElDorado National bus, BAE Systems hybrid propulsion system, Ballard fuel cell) with an upgraded design. Two buses were funded under the FTA's Transit Investments for Greenhouse Gas and Energy Reduction (TIGGER) Program. The first bus was put into service in June 2014. The second bus was delivered in August 2014. The third bus was originally planned for another transit agency, but when that agency lost access to hydrogen fueling the bus was transferred to SunLine. That bus went into service in May 2015. NREL is collecting data on all four AFCBs at SunLine. NREL's September 2015 report included performance data on these buses.

- Birmingham-Jefferson County Transit Authority: Birmingham Fuel Cell Bus Project-Demonstration of one 32-foot EVAmerica bus with an Embedded Power battery-dominant hybrid propulsion system using lithium titanate batteries and a Ballard fuel cell. The bus was delivered in early 2014 and was placed in service in June 2014.

- Capital Metro: Advanced Composite FCEB Demonstration-One-year demonstration of one 35-foot Proterra bus with a battery-dominant hybrid propulsion system, lithium titanate batteries, and a Hydrogenics fuel cell system.

- University of California, Irvine - Demonstration of one AFCB with the same design as the new buses at SunLine (ElDorado National bus, BAE Systems hybrid propulsion system, Ballard fuel cell). The University of California, Irvine received the bus in April 2015 and will begin service once the fall quarter begins. NREL is working with the university to collect data on the bus and will report on the performance once there are enough data.

- Flint MTA: Nutmeg FCEB - Demonstration of one Van Hool fuel cell hybrid bus with a fuel cell system by US Hybrid. This bus was one of the four buses originally operated by Connecticut Transit under the NFCBP project. At the conclusion of that demonstration, one bus was transferred to Flint. The agency operated the bus for more than a year. An issue with the hybrid system kept the bus out of service for an extended downtime. Flint MTA reports that the bus is now being repaired and will be placed back 
into service. NREL collected some of the early performance data on the bus, which was included in previous status reports.

- Flint MTA: AFCB - Demonstration of one AFCB of the same design as the newer buses at SunLine (ElDorado National bus, BAE Systems hybrid propulsion system, Ballard fuel cell). This bus was funded through the FTA TIGGER Program. The agency has received the bus and is currently preparing it for service.

The University of Delaware and Greater New Haven Transit District FCEB projects were funded through FTA outside of the NFCBP.

During the last year, NREL collected data on the FCEBs demonstrated in projects 1, 3, 4, 5, and 6 in Table 2. The section "Update of Evaluation Results Through July 2015" provides the most recent results for these demonstrations.

\section{National Fuel Cell Bus Program}

The NFCBP is a multi-year, cost-shared research program established by FTA in 2006, with an overall goal of developing and demonstrating commercially viable fuel cell technology for transit buses. Additional funding was added to the program over the following 4 years, bringing the total funds to nearly $\$ 90$ million. Projects were competitively selected and included fuel cell bus demonstrations, component development projects, and outreach projects. Three non-profit consortia - CALSTART (Pasadena, California), the Center for Transportation and the Environment (CTE, Atlanta, Georgia), and the Northeast Advanced Vehicle Consortium (NAVC, Boston, Massachusetts) — are responsible for managing the projects. NREL was funded as a third-party evaluator to assess the viability of the buses demonstrated under the program.

The NFCBP-funded demonstration projects that are currently underway are included in Table 2 (blue shaded rows). Table 3 lists the remaining demonstration projects that are expected to field seven more fuel cell buses over the next few years.

Table 3. New Fuel Cell Transit Buses Planned for the FTA NFCBP

\begin{tabular}{|l|l|c|l|}
\hline \multicolumn{1}{|c|}{ Project } & \multicolumn{1}{|c|}{ Location } & $\begin{array}{c}\text { Total } \\
\text { Buses }\end{array}$ & \multicolumn{1}{|c|}{ Technology Description } \\
\hline $\begin{array}{l}\text { Massachusetts FCEB Demo } \\
\text { (NAVC) }\end{array}$ & Boston, MA & 1 & $\begin{array}{l}\text { EIDorado/BAE Systems/Ballard next- } \\
\text { generation AFCB }\end{array}$ \\
\hline $\begin{array}{l}\text { Advanced Generation FCEB } \\
\text { (CALSTART) }\end{array}$ & TBD & 1 & $\begin{array}{l}\text { New Flyer 60-foot bus with next- } \\
\text { generation Hydrogenics fuel cell, Siemens } \\
\text { hybrid propulsion system }\end{array}$ \\
\hline $\begin{array}{l}\text { Next-Generation Compound } \\
\text { Bus (CALSTART) }\end{array}$ & $\begin{array}{l}\text { San Francisco, } \\
\text { CA }\end{array}$ & 1 & $\begin{array}{l}\text { BAE Systems diesel hybrid bus with fuel } \\
\text { cell auxiliary power unit for auxiliary loads } \\
\text { (next-generation system to the original } \\
\text { Compound bus) }\end{array}$ \\
\hline AFCB (CALSTART) & Canton, OH & 2 & $\begin{array}{l}\text { EIDorado/BAE Systems/Ballard next- } \\
\text { generation AFCB }\end{array}$ \\
\hline $\begin{array}{l}\text { Battery-Dominant FCEB } \\
\text { (CALSTART) }\end{array}$ & $\begin{array}{l}\text { Thousand } \\
\text { Palms, CA }\end{array}$ & 1 & $\begin{array}{l}\text { EIDorado bus with a battery-dominant } \\
\text { fuel cell system from BAE Systems and a } \\
\text { US Hybrid fuel cell }\end{array}$ \\
\hline $\begin{array}{l}\text { Central New York Fuel Cell } \\
\text { Transportation Program (CTE) }\end{array}$ & Ithaca, NY & 1 & $\begin{array}{l}\text { EIDorado/BAE Systems/Ballard next- } \\
\text { generation AFCB }\end{array}$ \\
\hline
\end{tabular}


Beyond the NFCBP, FTA has funded fuel cell bus research at several universities and transit agencies around the country. The TIGGER Program funded a number of zero-emission buses at transit agencies in the United States. The majority of those buses are battery-electric buses; however, SunLine and Flint MTA received funding for FCEBs. These TIGGER projects, listed in Table 2, include an upgraded AFCB design based on lessons learned from the first bus demonstrated at SunLine.

FTA's newest program is the Low or No Emission Vehicle Deployment Program-LoNo Program for short. This program provides funding for capital acquisitions or leases of zeroemission and low-emission transit buses, including battery electric buses (BEBs) and FCEBs. The primary purpose is to deploy the cleanest U.S.-made transit buses that have been proven in testing and demonstrations but are not yet widely deployed in transit fleets. Ten projects were awarded more than $\$ 54$ million in funding to add low- or zero-emission buses to transit fleets across the United States. A total of 60 buses will be deployed through the program: 10 FCEBs, 33 BEBs, and 17 hybrid electric buses. The FCEB projects include 10 AFCBs for two agencies; five will be deployed at SunLine and five will be deployed at Stark Area Regional Transit Authority in Canton, Ohio. 


\section{FCEB Development Process-Technology Readiness Levels}

In the 2012 status report, NREL introduced a guideline for assessing the technology readiness level (TRL) for FCEBs. This guideline was developed using a Technology Readiness Assessment Guide ${ }^{4}$ published by DOE in September 2011. NREL presented a TRL guide tailored for the commercialization of FCEBs. Figure 1 provides a graphic representation of this process. A table outlining the TRLs and definitions is included in the Appendix.

\section{Commercialization Process}

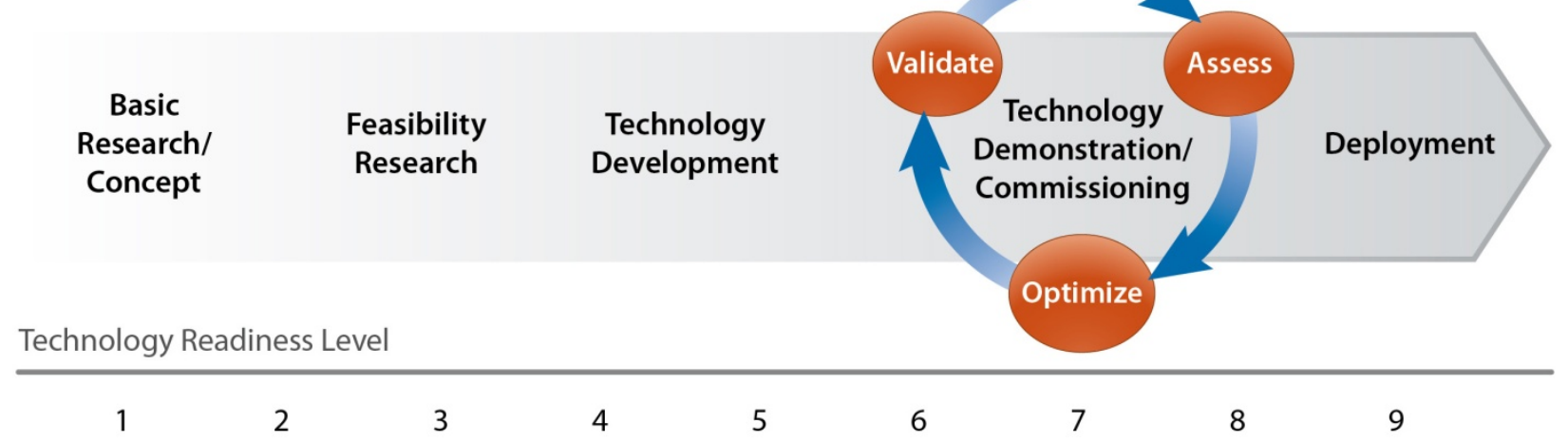

Figure 1. Graphic representation of the commercialization process developed for FCEBs

The technology demonstration/commissioning phase that includes TRLs 6 through 8 is the start of an iterative process to validate the design, analyze the results, and reconfigure or optimize the design as needed. The manufacturer typically works with a transit agency partner to conduct inservice tests on the bus. Updates to the design are made based on the performance results, and the buses go back into demonstration and through the cycle until the design meets the performance requirements. This can be a time-consuming process as manufacturers work through technical difficulties.

New manufacturer teams introducing designs of FCEBs in smaller numbers are placed in the first step of the technology demonstration/commissioning phase. As with previous reports, a designation of first-generation is given to the prototype designs from new manufacturer teams that fall in TRL 6; a second-generation system is typically a follow-on design from an existing team that falls in TRL 7. These designations are used in this report for simplicity and do not necessarily coincide with any version or designation made by the manufacturers.

At this point in the development process, FCEBs are not commercial products. The manufacturers' goals for the demonstration phase are to verify that the FCEB performance meets the technical targets and identify any issues that need to be resolved. The current costs for FCEB technology — both capital and operating costs - are still much higher than that of conventional diesel technology. This is expected considering diesel is a very mature technology (TRL 9) and FCEBs are still in the development stage. Once an advanced technology, such as FCEBs, meets the performance targets, the industry can work to reduce costs. This was the case with both

\footnotetext{
${ }^{4}$ DOE Technology Readiness Assessment Guide, G 143.3-4a, www.directives.doe.gov/directives/0413.3-EGuide$\underline{04 a / v i e w .}$
} 
compressed natural gas $(\mathrm{CNG})$ and diesel-hybrid bus technologies when they were first developed.

Table 4 lists the four manufacturer teams with FCEB designs that NREL is currently evaluating. This section, organized by bus original equipment manufacturer (OEM), describes each of these FCEBs and where they fall in the commercialization process outlined in Figure 1. The TRL determination for each FCEB type was made by NREL based on the descriptions in the FCEB TRL guide table (see Appendix). The designations are for each bus design as a whole package; individual components within the design might be commercially available products or prototypes. The first three manufacturer teams were described in the 2014 report. The TRL designations have not changed, but this section includes updates to the development status for each.

Table 4. Manufacturer Teams for FCEBs Currently Operating in North America

\begin{tabular}{|l|c|c|c|c|c|c|}
\hline Bus OEM & $\begin{array}{c}\text { Length } \\
(\mathrm{ft})\end{array}$ & $\begin{array}{c}\text { Fuel Cell } \\
\text { System }\end{array}$ & Hybrid System & $\begin{array}{c}\text { Design } \\
\text { Strategy }\end{array}$ & TRL & Energy Storage \\
\hline Van Hool & 40 & US Hybrid & $\begin{array}{c}\text { Siemens ELFA } \\
\text { integrated by } \\
\text { Van Hool }\end{array}$ & $\begin{array}{c}\text { Fuel cell } \\
\text { dominant }\end{array}$ & 7 & $\begin{array}{c}\text { Lithium-based } \\
\text { batteries }\end{array}$ \\
\hline EIDorado & 40 & Ballard & BAE Systems & $\begin{array}{c}\text { Fuel cell } \\
\text { dominant }\end{array}$ & 7 & $\begin{array}{c}\text { Lithium-based } \\
\text { batteries }\end{array}$ \\
\hline Proterra & 35 & Hydrogenics & Proterra & $\begin{array}{c}\text { Battery } \\
\text { dominant }\end{array}$ & 6 & $\begin{array}{c}\text { Lithium titanate } \\
\text { batteries }\end{array}$ \\
\hline EVAmerica & 32 & Ballard & $\begin{array}{c}\text { Embedded } \\
\text { Power }\end{array}$ & $\begin{array}{c}\text { Battery } \\
\text { dominant }\end{array}$ & 6 & $\begin{array}{c}\text { Lithium titanate } \\
\text { batteries }\end{array}$ \\
\hline
\end{tabular}

Van Hool-This bus design was based on an earlier-version Van Hool FCEB. The bus design includes a Siemens ELFA hybrid system integrated by Van Hool, a fuel cell system by US Hybrid, and energy storage by EnerDel. The ZEBA buses at AC Transit and the buses previously operating at Connecticut Transit are this design. As reported previously, this design is considered a second-generation product at TRL 7 because it involved 16 buses and the design includes upgrades based on the lessons learned from the previous FCEB.

EIDorado - The development of this NFCBP-funded FCEB design was led by the hybrid manufacturer/integrator BAE Systems in partnership with Ballard Power Systems and ElDorado. The system is based on BAE Systems' proven hybrid electric propulsion system that is commercially available for transit buses. The prototype bus has operated at SunLine for more than 3 years. The manufacturer team has worked together to transition the build process for the AFCBs into the standard build process at ElDorado. Under TIGGER Program funding, the team delivered two additional buses to SunLine that feature upgrades based on lessons learned with the prototype. Five buses were completed and delivered and there are more on order. Once all of the buses currently on order are delivered, there will be about 20 AFCBs operating in the United States. This bus is considered a second-generation product at TRL 7.

Proterra-This bus is an upgraded design based on the original bus funded under the NFCBP. Proterra used the experiences with the first-generation bus to update the design for this bus. Proterra's primary bus product is a BEB, offered in a fast-charge or extended-range plug-in version. The FCEB design begins the build process as an electric bus, with common components 
to the $\mathrm{BEB}$ version. Once it reaches the stage for installation of the fast-charge components, the FCEB version has the fuel cell and hydrogen storage system installed instead of the overhead charging system. The fuel cell acts as a range extender to the BEB model. NREL considers this bus a prototype design at TRL 6 .

EVAmerica - This bus design effort is led by Embedded Power and uses a Ballard fuel cell system with lithium titanate batteries. The 32-foot bus body was built by EVAmerica. The design of this bus was originally funded as an FTA university research project, but teaming issues caused delays in completing the bus build and demonstration phase. The project received additional funds through the NFCBP to complete the bus and support the demonstration in Birmingham, Alabama. This bus is considered an early prototype design at TRL 6.

Both ElDorado and Proterra produce transit buses for the U.S. market. Commercial FCEB products from these OEMs meet FTA's 'Buy America' requirements. The potential for a future U.S. FCEB product from the other two manufacturers is unclear. EVAmerica is currently insolvent and Van Hool is based in Belgium. However, the hybrid system providers could elect to move the FCEB design forward with another bus manufacturer. Another bus OEM-New Flyer-is currently developing a next-generation FCEB design. New Flyer's product line for the U.S market meets 'Buy America' requirements. The new FCEB design will increase the choices for transit agencies interested in adopting the technology. 


\section{Update of Evaluation Results Through July 2015}

The data presented in this section represent the most recent results that have not been presented in a previous annual status report. These data come from four different FCEB demonstrations. The data have been separated into two sections based on the TRL of the FCEBs. NREL has collected several years of data on the TRL 7 designs. These designs are closer to commercialization and can be reasonably combined for comparison. NREL has only collected data on the prototype TRL 6 designs for a few months. Selected results for these designs will be presented later in the report.

\section{FCEBs at TRL 7}

This section summarizes the data for the two FCEB designs at TRL 7. To simplify the presentation of the data, each FCEB is assigned an identifier that includes a site abbreviation followed by a manufacturer or project designation. The FCEBs presented in this section have hybrid systems that are fuel cell dominant. Table 5 provides some specifications for each FCEB by the unique identifier. The TRL 7 FCEBs are pictured in Figure 2.

Table 5. FCEB Identifiers and Selected Specifications

\begin{tabular}{|l|c|c|}
\hline & ACT ZEBA & SL AFCB \\
\hline Transit agency & AC Transit & SunLine \\
\hline Number of buses & 12 & 4 \\
\hline Bus OEM & Van Hool & EIDorado \\
\hline Model/year & A300L/2010 & $\begin{array}{c}\text { Axcess/2011 and } \\
2014\end{array}$ \\
\hline Bus length & $40 \mathrm{ft}$ & $40 \mathrm{ft}$ \\
\hline Gross vehicle weight & $39,350 \mathrm{lb}$ & $43,420 \mathrm{lb}$ \\
\hline Fuel cell OEM & US Hybrid & Ballard \\
\hline Fuel cell model & Puremotion 120 & FCvelocity HD6 \\
\hline Fuel cell power (kW) & 120 & 150 \\
\hline $\begin{array}{l}\text { Hybrid system } \\
\text { integrator }\end{array}$ & Van Hool & BAE Systems \\
\hline Design strategy & Fuel cell dominant & Fuel cell dominant \\
\hline Energy storage OEM & EnerDel & A123 \\
\hline Energy storage type & Li-ion & Li-ion \\
\hline $\begin{array}{l}\text { Energy storage } \\
\text { capacity }\end{array}$ & $21 \mathrm{kWh}$ & $11 \mathrm{kWh}$ \\
\hline $\begin{array}{l}\text { Hydrogen storage } \\
\text { pressure (psi) }\end{array}$ & 5,000 & 5,000 \\
\hline Hydrogen cylinders & 8 & 8 \\
\hline Hydrogen capacity (kg) & 40 & 50 \\
\hline TRL & 7 & 7 \\
\hline
\end{tabular}

\section{Baseline Buses}

Conventional baseline bus data are provided for comparison with FCEB data when comparable buses are available. Data on baseline buses were included for both sites. For AC Transit, the primary comparison is with two designs of diesel buses: Van Hool diesel buses that are the same model as the FCEBs and newer Gillig diesel buses. The Van Hool buses are the best physical match for the FCEBs; however, they are slightly older, have accumulated 4 times more miles than the FCEBs, and are no longer under warranty. These buses have reached mid-life, and 
maintenance records have begun to show increased cost typical of this period. The Gillig buses provide a comparison of the newest diesel technology to the FCEBs. The Gillig buses are younger; however, the mileage of each bus is closer to that of the FCEBs. The baseline buses at SunLine are CNG buses because the agency does not operate diesel buses. The Appendix summarizes the data results by demonstration location and provides additional charts that detail some of the results by agency.

Data periods included in the report-The report focuses on data from August 2014 through July 2015.

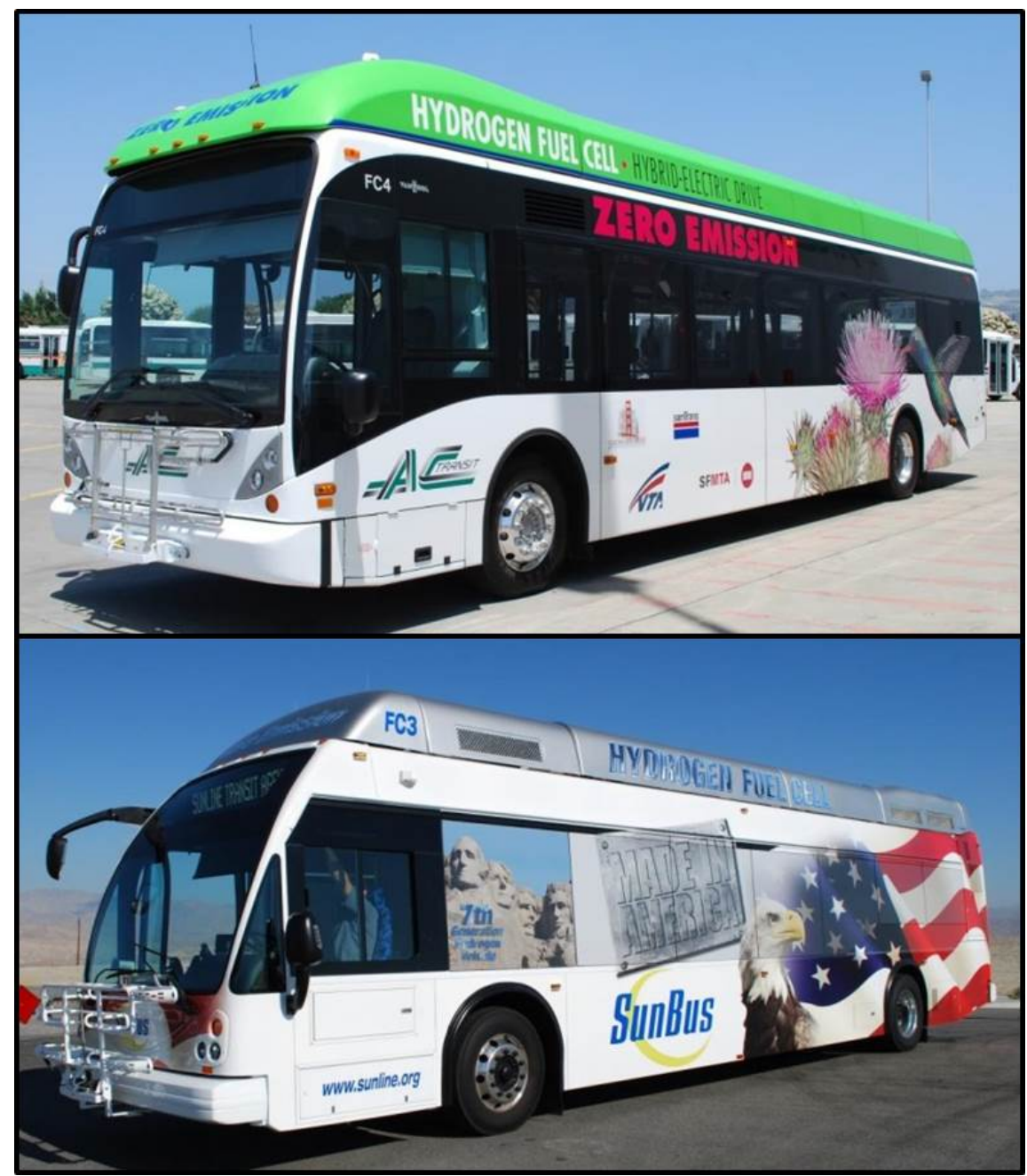

Figure 2. FCEBs at TRL 7: AC Transit ZEBA FCEB (top) and SunLine AFCB (bottom)

\section{Total Miles and Hours}

Table 6 shows miles, hours, average speed, and average monthly miles per bus for the FCEBs. The AFCBs at SunLine have the higher average speed at $13.7 \mathrm{mph}$. The ZEBA buses in service at AC Transit have a lower average speed of $8.9 \mathrm{mph}$. The average monthly miles for the group is 2,464 miles per month. This is higher than the average reported last year $(2,189$ miles per month). The average monthly miles for the ZEBA buses is slightly higher than last year. The 
average monthly miles for the SunLine AFCBs increased by $19 \%$ over that of the last reporting period.

Table 6. Miles and Hours for the FCEBs

\begin{tabular}{|l|c|c|c|c|c|c|c|}
\hline \multicolumn{1}{|c|}{ ID } & Period & Months & $\begin{array}{c}\text { No. of } \\
\text { Buses }\end{array}$ & Miles & Hours & $\begin{array}{c}\text { Avg. Speed } \\
(\mathrm{mph})\end{array}$ & $\begin{array}{c}\text { Avg. Monthly } \\
\text { Miles }\end{array}$ \\
\hline ACT ZEBA & $8 / 14-7 / 15$ & 12 & 12 & 360,587 & 40,599 & 8.9 & 2,504 \\
\hline SL AFCB & $8 / 14-7 / 15$ & 12 & 4 & 80,439 & 5,869 & 13.7 & 2,298 \\
\hline Overall FCEB & & & & 441,026 & 46,468 & 9.5 & 2,464 \\
\hline
\end{tabular}

\section{Bus Use}

Figure 3 shows the average monthly bus use for the FCEBs and the respective baseline buses.

The target of 3,000 miles is included on the chart. Both transit agencies continue to operate their FCEBs for fewer miles than they operate their baseline buses.

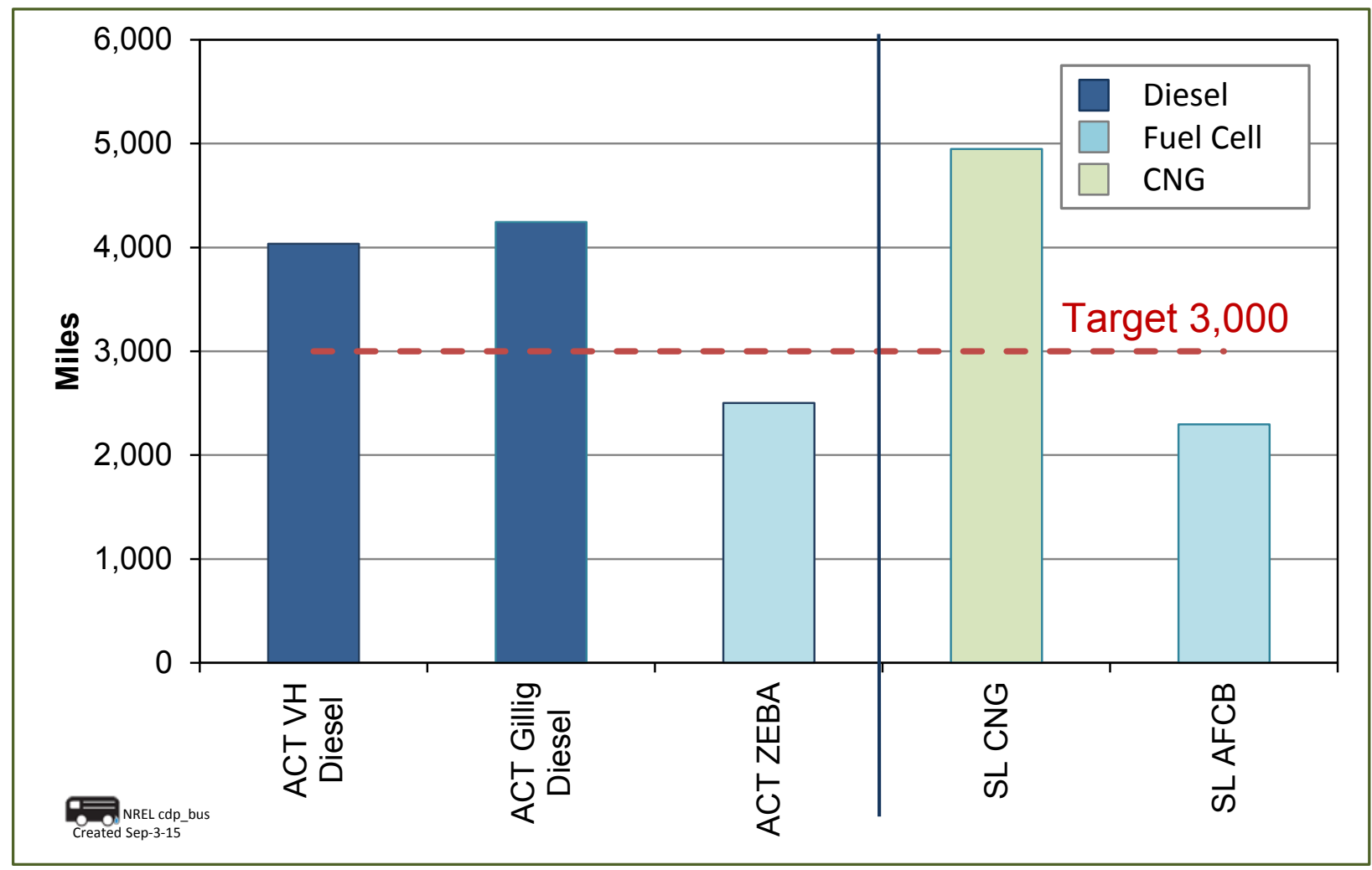

Figure 3. Average monthly mileage for the FCEBs and baseline buses

\section{Availability}

Availability is the percentage of days the buses are actually available out of days that buses are planned for operation. Availability for all of NREL's evaluations is calculated by including the planned service days, which are typically every weekday. Weekends and holidays are included in the calculation only if the bus operated in service on those days. If a bus does not operate on the weekend or on a holiday, it is not counted as unavailable. At AC Transit, the buses are planned to operate every day. At SunLine, the buses are typically planned to operate on weekdays; 
however, they often operate on weekends as well. Table 7 summarizes the availability of the fuel cell buses at each transit agency. Availability for both fleets was similar, with an average availability of $74 \%$ for the group. Figure 4 tracks the monthly availability for the FCEBs by project. The percent availability is shown as a separate colored line for each of the projects with the combined overall average for all of the FCEBs in dashed orange. The availability of the fuel cell system is also included on the chart as a green line. During the early part of the data period, the fuel cell system availability was higher than the DOE/FTA target of $90 \%$.

Table 7. Availability for the FCEBs

\begin{tabular}{|l|c|c|c|c|c|c|}
\hline \multicolumn{1}{|c|}{ ID } & Period & Months & No. of Buses & Planned Days & Days Avail. & $\%$ Avail. \\
\hline ACT ZEBA & $8 / 14-7 / 15$ & 12 & 12 & 4,380 & 3,283 & $75 \%$ \\
\hline SL AFCB & $8 / 14-7 / 15$ & 12 & 4 & 920 & 659 & $72 \%$ \\
\hline Overall FCEB & & & & 5,300 & 3,942 & $74 \%$ \\
\hline
\end{tabular}

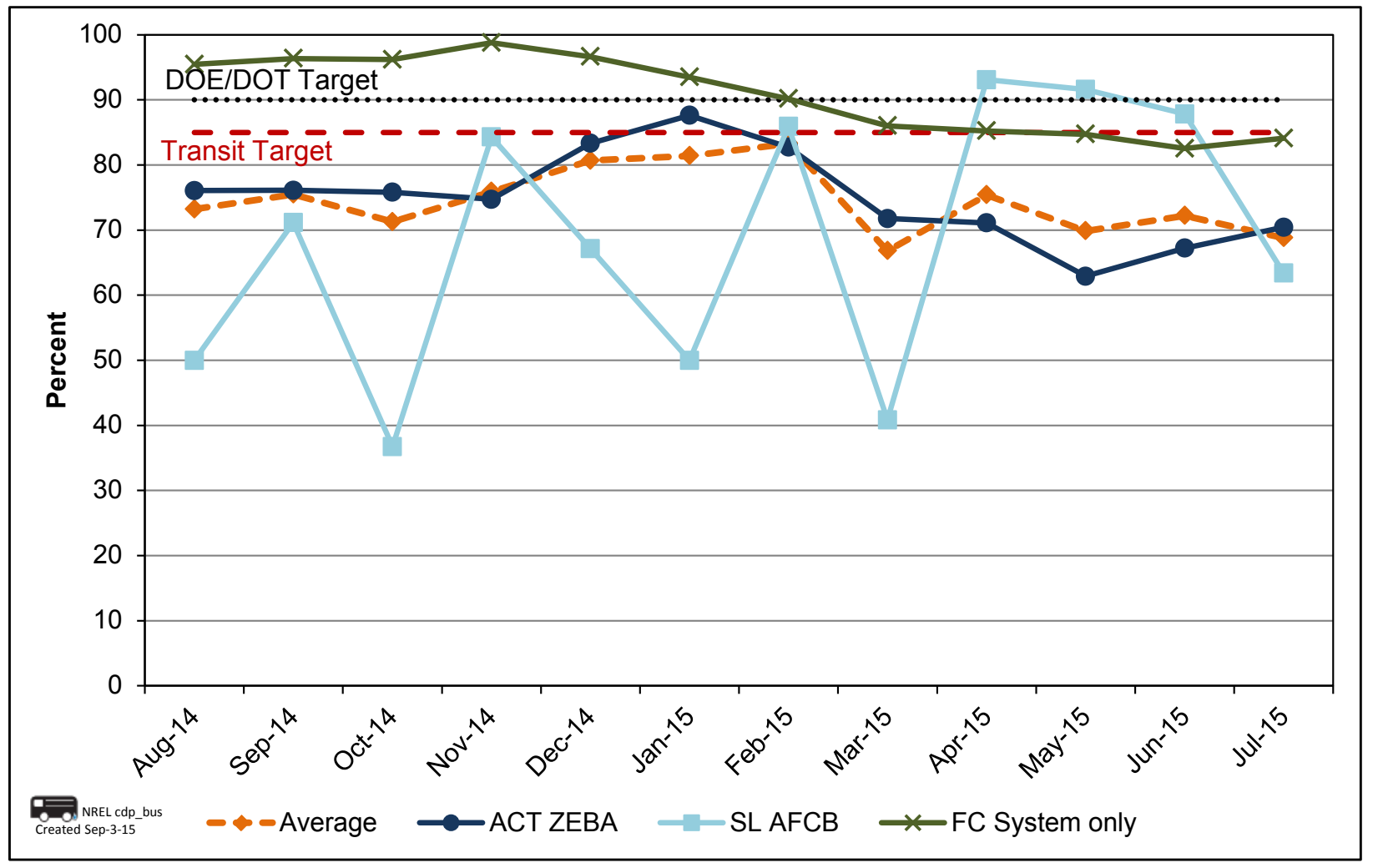

Figure 4. Monthly availability for the FCEBs

Availability for the ACT ZEBA FCEBs (dark blue line) was more than $70 \%$ for the majority of the data period. Availability was increasing in the early part of the data period as AC Transit stepped up its operation of the buses. Toward the end of the period, AC Transit began to experience issues that appear to be related to the fuel cell balance of plant in two of its buses. The problems have proven difficult to diagnose and have kept both buses out of service for an extended period of time. 
Availability for the SL AFCBs (light blue line) has fluctuated over the data period. Issues with the buses included problems with bus systems such as air compressors and windshields.

Downtime for propulsion-system-related components included a battery refresh on the prototype bus and system upgrades to two other buses. Issues with the fuel cell system were mostly related to balance of plant components.

Figure 5 presents individual pie charts that show the reasons for unavailability by category for each of the demonstrations over the data period. The data provided for the demonstrations at SunLine and AC Transit included the specific reason for each day a bus was not available. This categorization is based on the diagnostic information at that time. Occasionally, an issue proves challenging to troubleshoot and the cause is eventually traced to a system other than that of the original diagnosis. For these cases, NREL changes the unavailability reason retroactively to reflect the updated information. For AC Transit, problems with the fuel cell system were most common, followed by bus-related components. For the AFCBs, the majority of problems have been related to the hybrid propulsion system, followed by bus-related components.

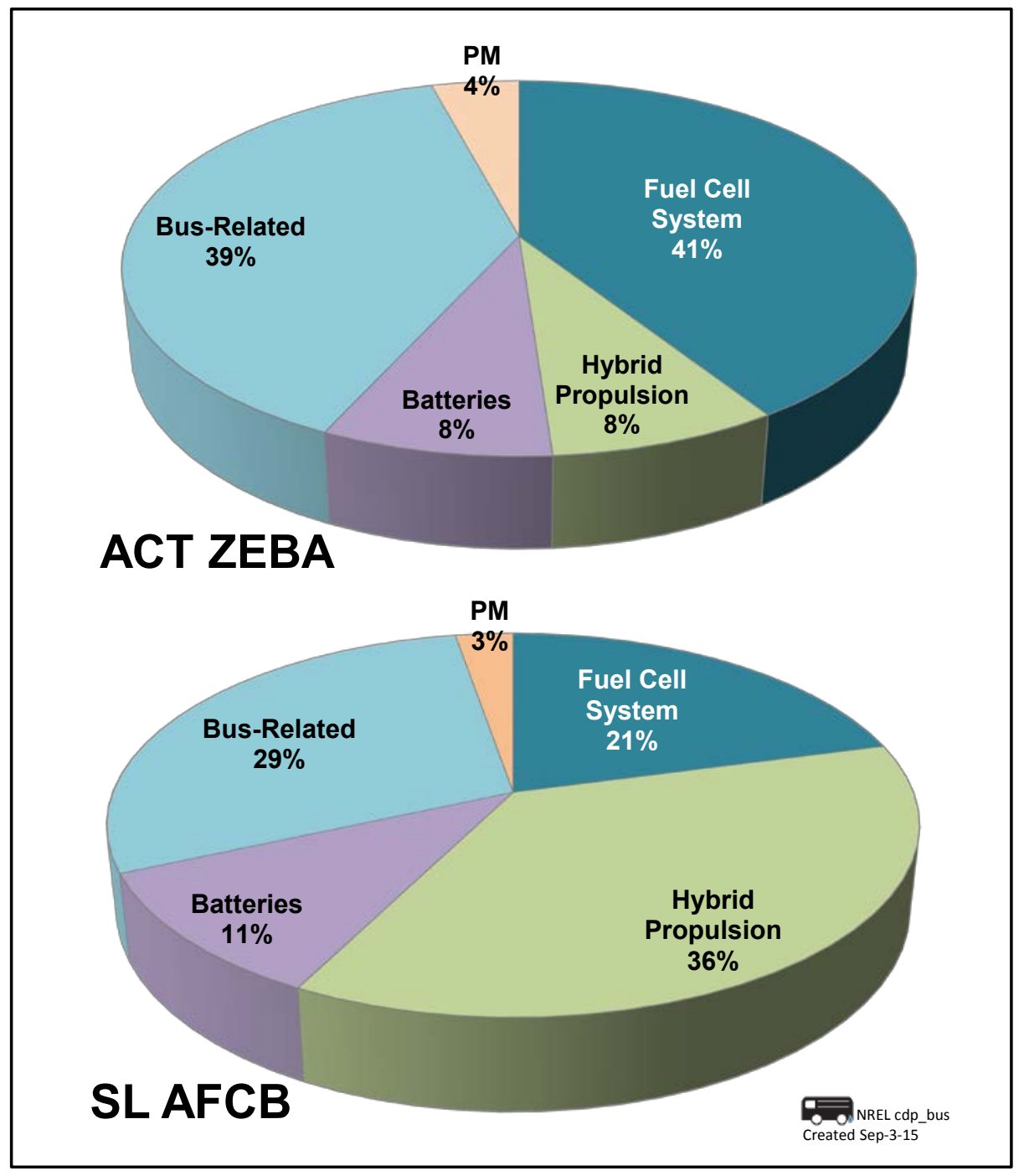

Figure 5. Reasons for unavailability for the FCEBs 


\section{Fuel Economy}

Table 8 shows the average fuel economy in miles per diesel gallon equivalent (DGE) for each type of FCEB compared to the conventional baseline bus technology at the same site. The AC Transit ZEBA buses are compared to both Van Hool (VH) and Gillig diesel buses. The fuel economy for the ZEBA buses is 1.7 times higher than that of the Van Hool diesel buses and 1.6 times higher than that of the Gillig buses. The AFCBs at SunLine show improved fuel economy that is almost 2 times higher than that of the CNG baseline buses.

Table 8. Average Fuel Economy Comparisons Between the FCEBs and Baseline Buses

\begin{tabular}{|l|c|c|c|}
\hline \multicolumn{1}{|c|}{ ID } & $\begin{array}{c}\text { Miles per } \mathrm{kg} \\
\text { or GGE }^{\mathrm{a}}\end{array}$ & Miles per DGE & $\begin{array}{c}\text { Difference } \\
\text { from Baseline }\end{array}$ \\
\hline ACT ZEBA & 5.96 & 6.74 & $1.73 x / 1.60 \mathrm{x}$ \\
\hline ACT VH diesel & - & 3.90 & - \\
\hline ACT Gillig diesel & - & 4.20 & - \\
\hline SL AFCB & 5.69 & 6.43 & $1.95 \mathrm{x}$ \\
\hline SL CNG & 2.94 & 3.29 & - \\
\hline
\end{tabular}

${ }^{\mathrm{a}} \mathrm{GGE}$ : Gasoline gallon equivalent.

Figure 6 shows the fuel economy by month over the last year. The FCEBs continue to show improved fuel economy compared to the baseline buses in similar service. The fuel economy for hybrid fuel cell systems tends to vary from site to site depending on the duty cycle.

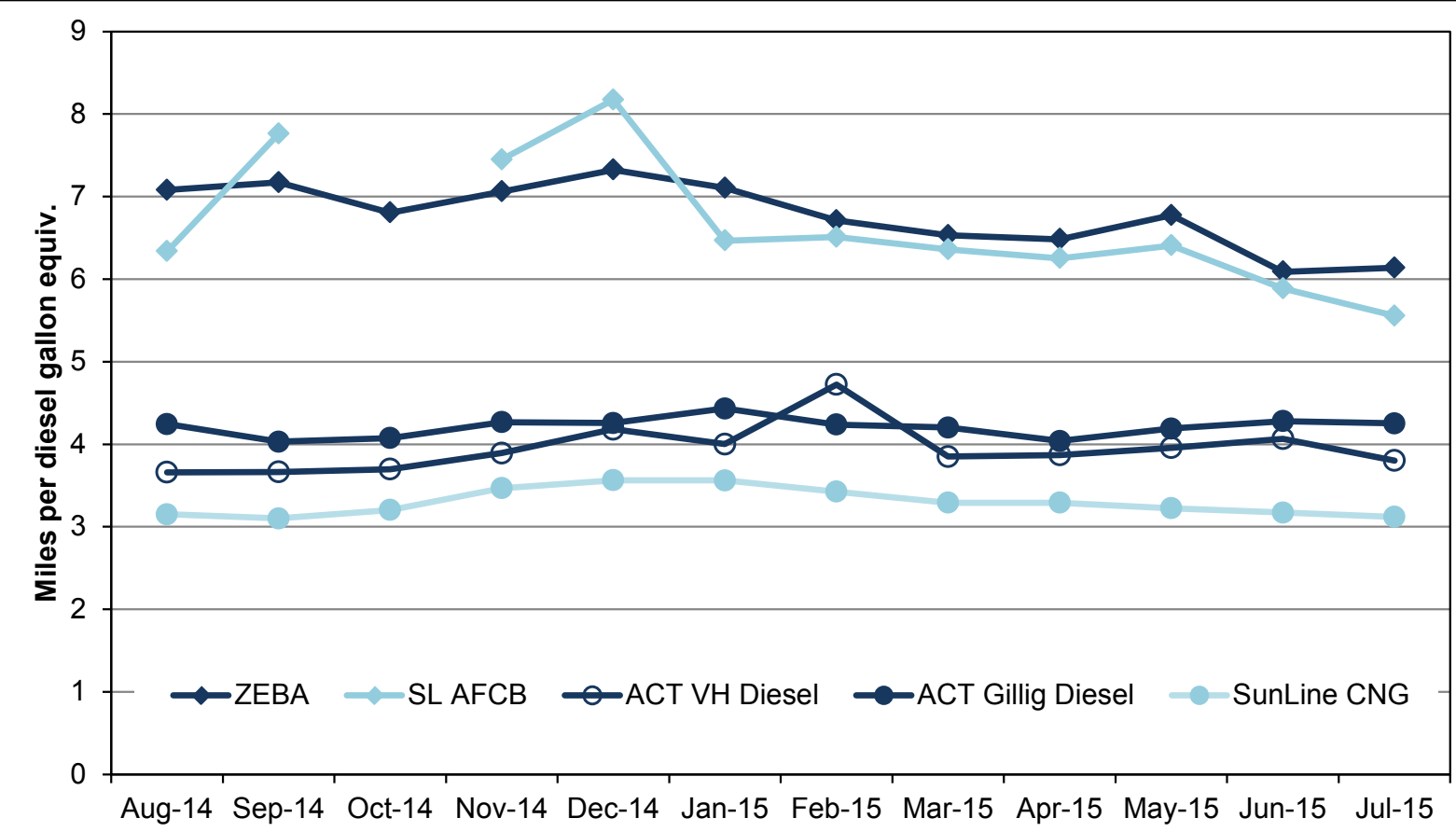

Figure 6. Fuel economy for FCEBs and baseline buses 


\section{Reliability-Miles Between Roadcalls}

A roadcall or revenue vehicle system failure (see the National Transit Database ${ }^{5}$ ) is a failure of an in-service bus that causes the bus to be replaced on route or causes a significant delay in schedule. If the bus is repaired during a layover and the schedule is maintained, then no roadcall is recorded. Figure 7 shows miles between roadcalls (MBRC) for bus roadcalls, ${ }^{6}$ propulsionrelated roadcalls ${ }^{7}$, and fuel-cell-system-related roadcalls ${ }^{8}$ for the FCEBs during the data period. The dark blue hashed line marks the DOE/FTA target for bus MBRC $(4,000)$, and the green hashed line is the target for fuel-cell-system-related MBRC $(20,000)$. A secondary target of 10,000 MBRC for propulsion systems is marked with a light blue hashed line. This is not one of the DOE/FTA targets; however, it is a general target for the transit industry. While the MBRC rates are still lower than the targets, the MBRC for fuel-cell-system-related roadcalls shows that the reasons are not typically due to the fuel cell.

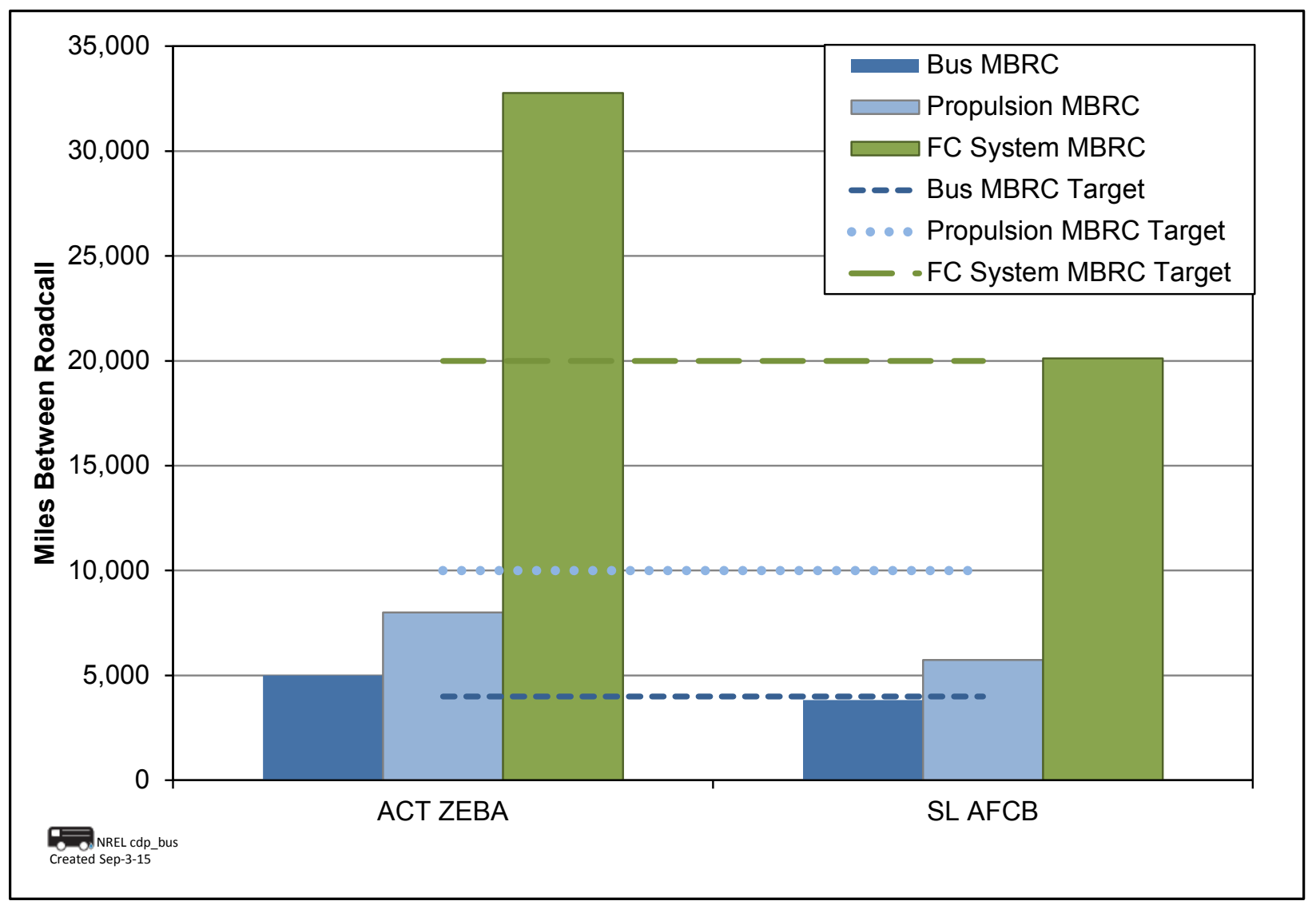

Figure 7. MBRC rates for FCEBs compared to the targets

\footnotetext{
${ }^{5}$ National Transit Database website: $\underline{w w w . n t d p r o g r a m . g o v / n t d p r o g r a m / . ~}$

${ }^{6}$ Bus MBRC is all chargeable roadcalls including propulsion-related issues as well as problems with bus-related systems such as brakes, suspension, steering, windows, doors, and tires.

${ }^{7}$ Propulsion-related MBRC includes roadcalls that are attributed to the propulsion system. Propulsion-related roadcalls can be caused by issues with the power system (fuel cell), batteries, and hybrid systems.

${ }^{8}$ Fuel-cell-system-related MBRC includes roadcalls attributed to the fuel cell power plant and balance of plant only.
} 


\section{Hydrogen Fueling}

NREL tracks total hydrogen use for FCEBs at all of the sites. Figure 8 shows the total hydrogen dispensed over time for the two sites since the current buses went into service through July 2015. Since that time, these FCEBs were fueled with more than $221,000 \mathrm{~kg}$ of hydrogen. During the past year at the two transit sites, the FCEBs were fueled 3,547 times with a total of $72,854 \mathrm{~kg}$ of hydrogen. The average fill amount for these fuel-cell-dominant FCEBs was $20.5 \mathrm{~kg}$ per fill.

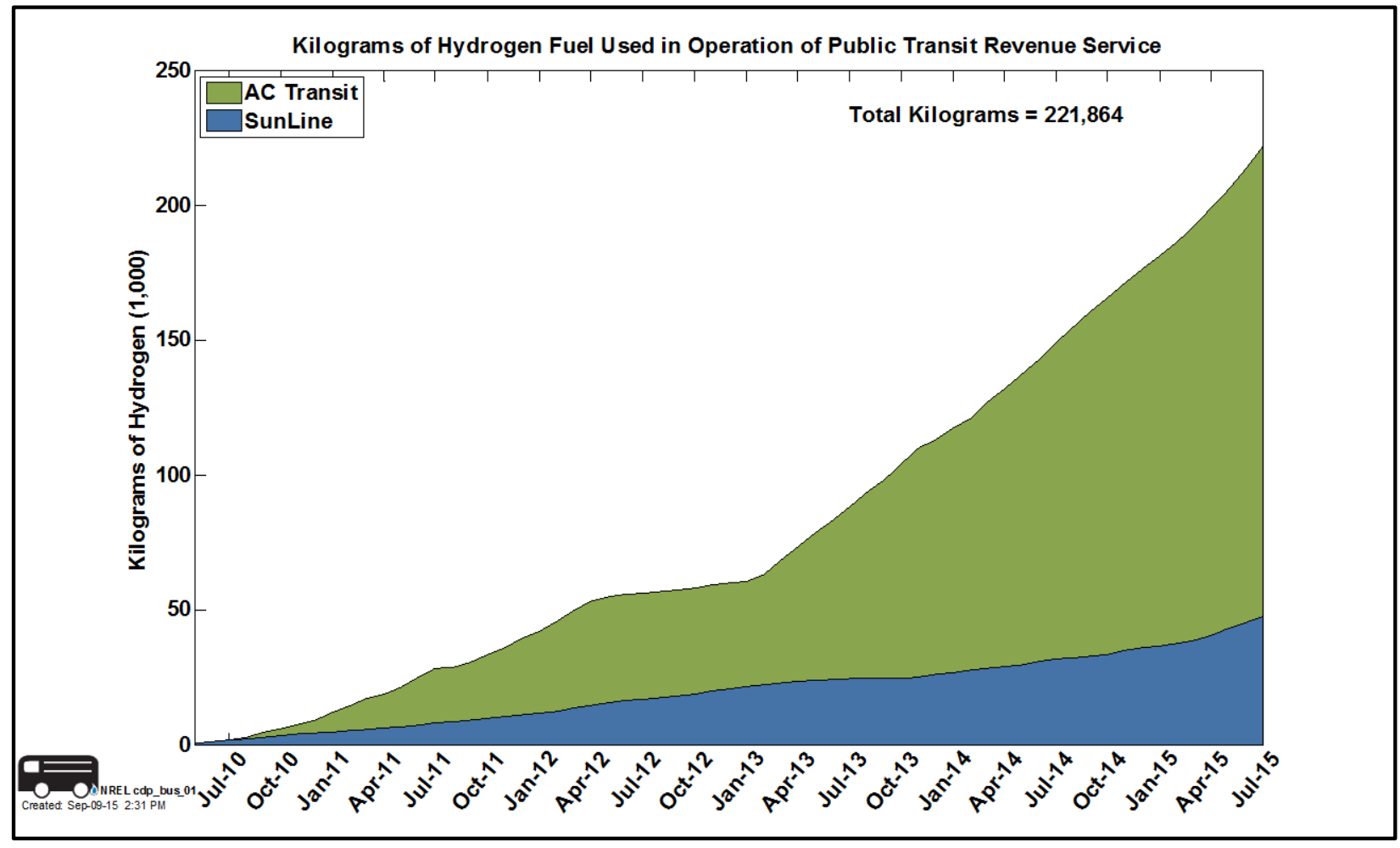

Figure 8. Hydrogen dispensed for the FCEBs through July 2015

\section{Early Generation FCEBs at TRL 6}

This section summarizes the data for two prototype FCEB designs at TRL 6. For these FCEBs, each design is designated by the site abbreviation. The FCEBs presented in this section have battery-dominant, plug-in hybrid systems that use smaller fuel cells mostly as a range extender. Table 9 provides some specifications for each FCEB by the unique identifier. The two TRL 6 FCEBs are pictured in Figure 9. 
Table 9. FCEB Identifiers and Selected Specifications

\begin{tabular}{|l|c|c|}
\hline Transit agency & MAX & CapMetro \\
\hline Number of buses & $\begin{array}{c}\text { BJCTA, } \\
\text { Birmingham, } \\
\text { AL }\end{array}$ & $\begin{array}{c}\text { Capital Metro, } \\
\text { Austin, TX }\end{array}$ \\
\hline Bus OEM & 1 & 1 \\
\hline Model/year & NVAmerica & Proterra \\
\hline Bus length & $32 \mathrm{ft}$ & HFC-35/2009 \\
\hline Curb weight & $25,344 \mathrm{lb}$ & $27,680 \mathrm{lb}$ \\
\hline Fuel cell OEM & Ballard & Hydrogenics \\
\hline Fuel cell model & HD6 & HyPM \\
\hline Fuel cell power (kW) & 75 & 60 (30x2) \\
\hline $\begin{array}{l}\text { Hybrid system } \\
\text { integrator }\end{array}$ & $\begin{array}{c}\text { Embedded } \\
\text { Power } \\
\text { Controls }\end{array}$ & Proterra \\
\hline Design strategy & $\begin{array}{c}\text { Battery } \\
\text { dominant }\end{array}$ & $\begin{array}{c}\text { Battery } \\
\text { dominant }\end{array}$ \\
\hline Energy storage OEM & Altairnano & Altairnano \\
\hline Energy storage type & Li-titanate & Li-titanate \\
\hline $\begin{array}{l}\text { Energy storage } \\
\text { capacity }\end{array}$ & $54 \mathrm{kWh}$ & $54 \mathrm{kWh}$ \\
\hline $\begin{array}{l}\text { Hydrogen storage } \\
\text { pressure (psi) }\end{array}$ & 5,000 & 5,000 \\
\hline Hydrogen cylinders & 5 & 4 \\
\hline Hydrogen capacity (kg) & 25 & 29 \\
\hline TRL & 6 & 6 \\
\hline
\end{tabular}

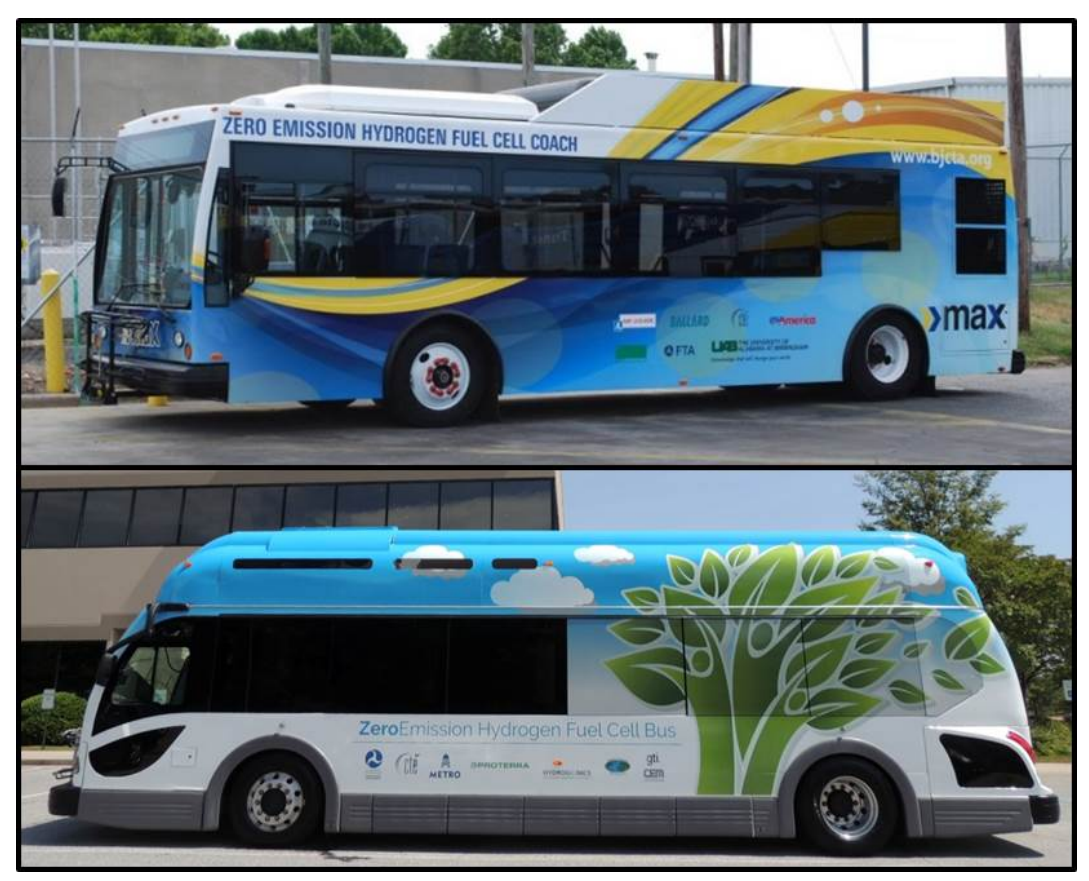

Figure 9. FCEBs at TRL 6: BJCTA FCEB (top) and CapMetro FCEB (bottom, photo courtesy of CTE) 
NREL began working with these two demonstration teams to evaluate the newest NFCBP bus prototypes in 2014. The first of these buses was placed into service at BJCTA — otherwise known as MAX - in May 2014. NREL has collected data for this bus through June 2015. There were several issues during the early phase of operation that kept the bus out of service for extended downtimes. The CapMetro FCEB was placed into service in January 2015. As early-generation prototypes, these designs are in the beginning stage of demonstration and evaluation. During this stage, the manufacturers are enlisting the help of transit agencies to conduct field tests and shakedown of the design in a real world environment. NREL has collected a limited set of data on the buses. Table 10 summarizes the data collected to date.

Table 10. Summary of Early Performance for TRL 6 FCEBs

\begin{tabular}{|l|c|c|}
\hline & MAX & CapMetro \\
\hline Data period & $5 / 14-6 / 15$ & $1 / 15-6 / 15$ \\
\hline Number of buses & 1 & 1 \\
\hline Number of months & 11 & 6 \\
\hline Total miles & 5,291 & 3,281 \\
\hline Total fuel cell hours & N/A & 966 \\
\hline Average miles per month & 481 & 547 \\
\hline Number of scheduled days & 304 & 84 \\
\hline Number of days available & 105 & 49 \\
\hline Availability (\%) & 35 & 58 \\
\hline Fuel economy (miles per kg) & 6.29 & 6.16 \\
\hline Fuel economy (miles per DGE) & 7.10 & 6.96 \\
\hline Bus MBRC & 529 & 562 \\
\hline Propulsion-related MBRC & 756 & 2,810 \\
\hline Fuel-cell-system-related MBRC & 1,764 & 2,810 \\
\hline Total hydrogen used (kg) & 842 & 533 \\
\hline
\end{tabular}




\section{Current Status of FCEB Introductions: Summary of Achievements and Challenges}

FCEB technology continues to show progress toward meeting technical targets for increasing reliability and durability while also reducing costs. This section discusses the progress being made and the challenges that remain to bring FCEBs to the market.

\section{Progress Toward Meeting Technical Targets}

In 2012, DOE and FTA established performance and cost targets for FCEBs in a Fuel Cell Technologies Program Record. ${ }^{9}$ Interim targets were set for 2016 along with ultimate targets that FCEBs would need to meet to compete with current commercial-technology buses. Table 11 shows a selection of these technical targets for FCEBs.

Table 11. DOE/FTA Performance, Cost, and Durability Targets for FCEBs ${ }^{a}$

\begin{tabular}{|c|c|c|c|}
\hline & Units & 2016 Target & Ultimate Target \\
\hline Bus lifetime & years/miles & $12 / 500,000$ & $12 / 500,000$ \\
\hline Power plant lifetime ${ }^{b}$ & hours & 18,000 & 25,000 \\
\hline Bus availability & $\%$ & 85 & 90 \\
\hline Fuel fills & per day & $1(<10 \mathrm{~min})$ & $1(<10 \mathrm{~min})$ \\
\hline Bus cost ${ }^{c}$ & $\$$ & $1,000,000$ & 600,000 \\
\hline $\begin{array}{l}\text { Roadcall frequency } \\
\text { (bus/fuel cell system) }\end{array}$ & MBRC & $3,500 / 15,000$ & $4,000 / 20,000$ \\
\hline Operation time & $\begin{array}{c}\text { hours per day/days } \\
\text { per week }\end{array}$ & $20 / 7$ & $20 / 7$ \\
\hline $\begin{array}{l}\text { Scheduled and } \\
\text { unscheduled } \\
\text { maintenance cost }^{d}\end{array}$ & \$/mile & 0.75 & 0.40 \\
\hline Range & miles & 300 & 300 \\
\hline Fuel economy & miles per DGE & 8 & 8 \\
\hline
\end{tabular}

${ }^{a}$ The cost targets for subsystems (power plant and hydrogen storage) are not included.

${ }^{\mathrm{b}}$ The power plant is defined as the fuel cell system and the battery system.

${ }^{c}$ Cost is projected to a production volume of 400 systems per year. This production volume is assumed for analysis purposes only and does not represent an anticipated level of sales.

${ }^{\mathrm{d}}$ Excludes mid-life overhaul of power plant.

Table 12 presents the current status for the TRL 7 FCEBs toward meeting the DOE/FTA targets. The data are presented for the two fleets (AC Transit and Sunline) as a group - that is, data are combined for all 16 buses. The table includes the fleet minimum and maximum as well as the overall average for the buses as a group. The data for this section include the life and performance beginning at the clean point for each bus.

\footnotetext{
${ }^{9}$ Fuel Cell Technologies Program Record \# 12012, September 12, 2012, www.hydrogen.energy.gov/pdfs/12012_fuel_cell_bus_targets.pdf.
} 
Table 12. Current Status Toward Meeting Performance Targets ${ }^{10}$

\begin{tabular}{|l|c|c|c|}
\hline & $\begin{array}{c}\text { Fleet } \\
\text { Minimum }\end{array}$ & $\begin{array}{c}\text { Fleet } \\
\text { Maximum }\end{array}$ & $\begin{array}{c}\text { Fleet } \\
\text { Average }\end{array}$ \\
\hline Bus lifetime (years) & 0.25 & 4.9 & 3.6 \\
\hline Bus lifetime (miles) & 7,978 & 117,217 & 81,108 \\
\hline Power plant lifetime (hours) & 667 & 20,024 & 10,102 \\
\hline Bus availability (\%) & 40 & 92 & 73 \\
\hline Fuel fills (number per day) & 1 & 1 & 1 \\
\hline Bus cost (\$) & $2.1 \mathrm{M}$ & $2.4 \mathrm{M}$ & $2.25 \mathrm{M}$ \\
\hline Roadcall frequency - bus (MBRC) & 1,809 & 6,849 & 4,280 \\
\hline Roadcall frequency - fuel cell system (MBRC) & 9,045 & 104,886 & 20,531 \\
\hline Operation time (average hours per day) & 7.4 & 13.7 & 11.8 \\
\hline $\begin{array}{l}\text { Scheduled and unscheduled maintenance } \\
\text { cost (\$/mile) }\end{array}$ & 0.54 & 1.33 & 1.16 \\
\hline Range (miles) & 242 & 345 & 275 \\
\hline Fuel economy (miles per DGE) & 5.56 & 7.71 & 6.8 \\
\hline
\end{tabular}

\section{Bus and Power Plant Lifetime}

The FTA minimum life cycle requirement for a full-size bus is 12 years or 500,000 miles. ${ }^{11} \mathrm{~A}$ fuel cell power plant (FCPP) needs to last about half of that time; this compares to a diesel engine that is often rebuilt at about the mid-life of the bus. DOE/FTA set an ultimate performance target of 4-6 years (or 25,000 hours) durability for the fuel cell propulsion system, with an interim target of 18,000 hours by 2016. In last year's report, NREL documented a single FCPP surpassing 17,000 hours without repair or cell replacement. At the end of the analysis period for this report (July 2015), that FCPP had surpassed 20,000 hours. Figure 10 shows the total hours accumulated on the FCPPs for the AC Transit ZEBA fleet (blue bars) and the SunLine AFCB fleet (orange bars). The DOE/FTA targets for FCPP hours are highlighted in the figure as a green hashed line for the 2016 target and an orange hashed line for the ultimate target; the group average for the 16 FCPPs of 10,102 hours is shown as a red hashed line. Of the 16 total FCPPs included in the graph, 75\% (12) have surpassed 10,000 hours of operation. This shows continued improvement over time toward meeting the 25,000 hour target.

\footnotetext{
${ }^{10}$ Fleet minimum and maximums are for each performance metric and may not necessarily be for the same bus.

${ }^{11}$ FTA Circular 5010.1D: Grant Management Requirements, page IV-17, www.fta.dot.gov/legislation_law/12349_8640.html.
} 


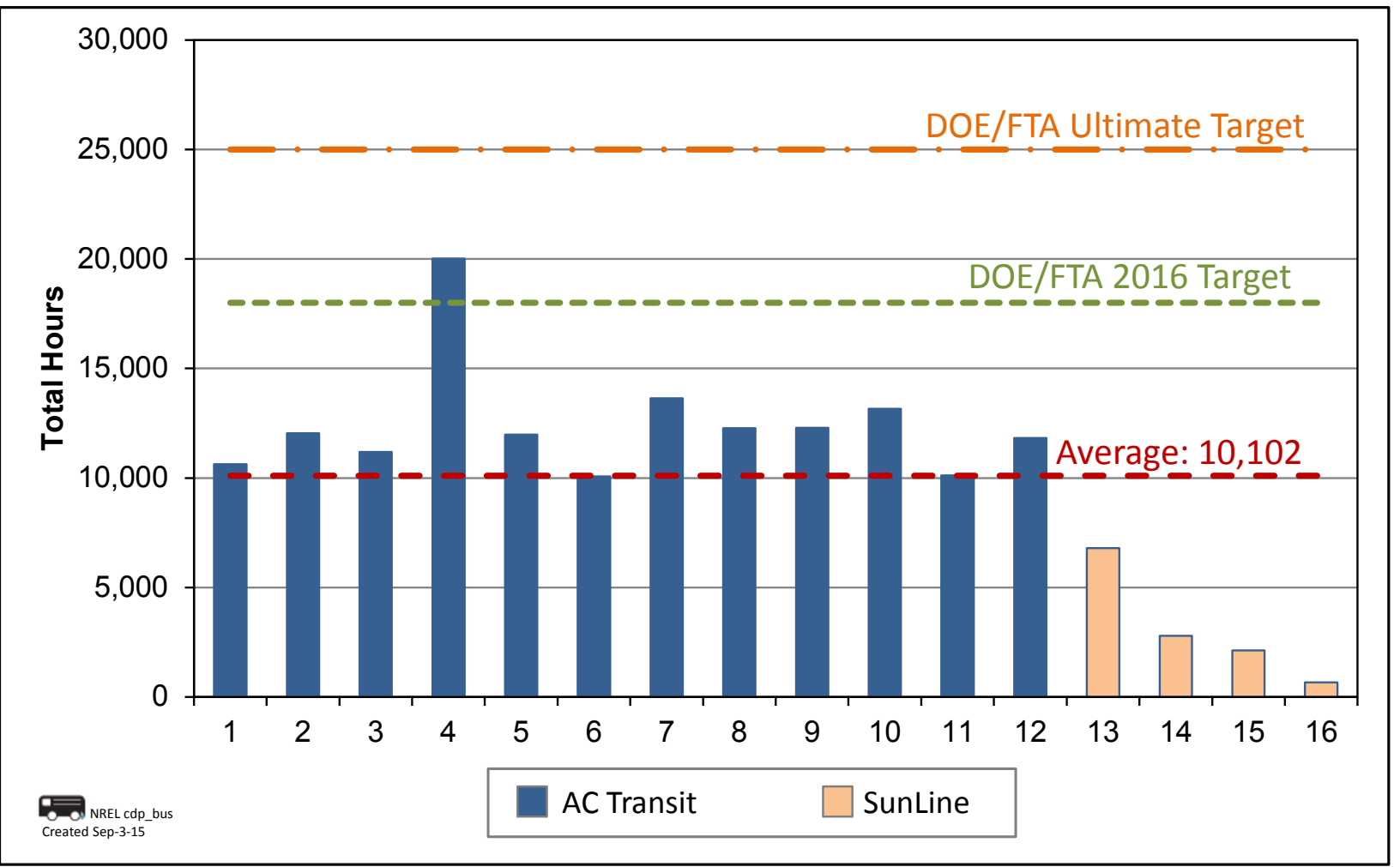

Figure 10. Total hours on the FCEBs through July 2015

\section{Bus Availability}

Availability for the FCEBs ranges from a low of $40 \%$ to a high of $92 \%$ with an overall average of $74 \%$. This is an increase over what was reported in the 2014 report. Many of the issues are attributed to bus-related problems such as windshields and cooling pumps. In the last year, both agencies have seen an increase in issues related to the hybrid system, batteries, and fuel cell systems. Downtime has been extended in some cases because intermittent issues are difficult to troubleshoot. On several occasions, the original diagnosis of the problem was eventually traced to another system. Transit staff continues to learn about the systems and become more proficient in troubleshooting and repairing issues. Downtime is expected to decrease over time.

\section{Fuel Fills}

Transit agencies typically fuel and service buses each evening to prepare them for morning pullout the following day. This results in a 6 to 8 hour window for all of the buses at a specific depot to be prepped. As the buses are being fueled, transit staff is handling other prep work, such as cleaning the interior and emptying the farebox. The time to service each bus is about 10 minutes; therefore the fueling time needs to be 10 minutes or less. Both transit agencies are able to fuel the buses at least once per day. Times for fueling vary between fleets, mainly due to the station designs. SunLine's station typically dispenses hydrogen at about $1 \mathrm{~kg}$ per minute, resulting in an average fill time of 22 minutes. AC Transit's stations can fill at rates up to $5 \mathrm{~kg}$ per minute, which results in fill times of less than 10 minutes. 


\section{Bus Cost}

At this point in the development of FCEB technology, costs are still high. DOE/FTA has set a 2016 target for capital cost of $\$ 1$ million per bus with an ultimate target of $\$ 600,000$ per bus. With increased orders for FCEBs, the capital cost has dropped significantly. For the most recent order for AFCBs-10 buses for SunLine and Stark Area Regional Transit Authority - the cost per bus was $\$ 1.8$ million. Previous versions were $\$ 2.4$ million. This cost should continue to decrease with larger orders of buses. The industry projects an order for 40 buses could result in costs closer to $\$ 1$ million each.

\section{Roadcall Frequency}

The transit industry measures reliability as mean distance between failures, also documented as MBRC. The DOE/FTA targets for roadcall frequency include MBRC for the entire bus and MBRC for the fuel cell system only. Bus MBRC includes all chargeable roadcalls, which means any issue that could physically disable the bus from operating on route. It does not include roadcalls for items such as fareboxes, radios, or destination signs. The fuel cell system MBRC includes any roadcalls due to issues with the fuel cell stack or associated balance of plant.

Each year, NREL presents summary data from the most recent evaluations. As demonstrations end, the data from those evaluations are removed from the combined calculations, while others are added. This makes it challenging to compare the current year's data to previous years because the data set can change significantly. Last year's report included the 20-bus fleet demonstration at BC Transit, which ended in March 2014. That demonstration was removed from this year's data set for the analysis. To better illustrate the trend over time for the FCEB designs included in this report, the following MBRC results include reliability data from the two current fleets back to the beginning of the evaluation periods. Figure 11 shows the monthly MBRC over time for both bus demonstrations combined. The DOE/FTA 2016 and ultimate targets for bus MBRC and fuel cell (FC) system MBRC are included as dashed lines on the chart. Bus MBRC shows a general upward trend, surpassing the 2016 target and reaching the ultimate target at the end of the data period. Fuel cell system MBRC shows a steady upward trend over time, also surpassing the ultimate target. 


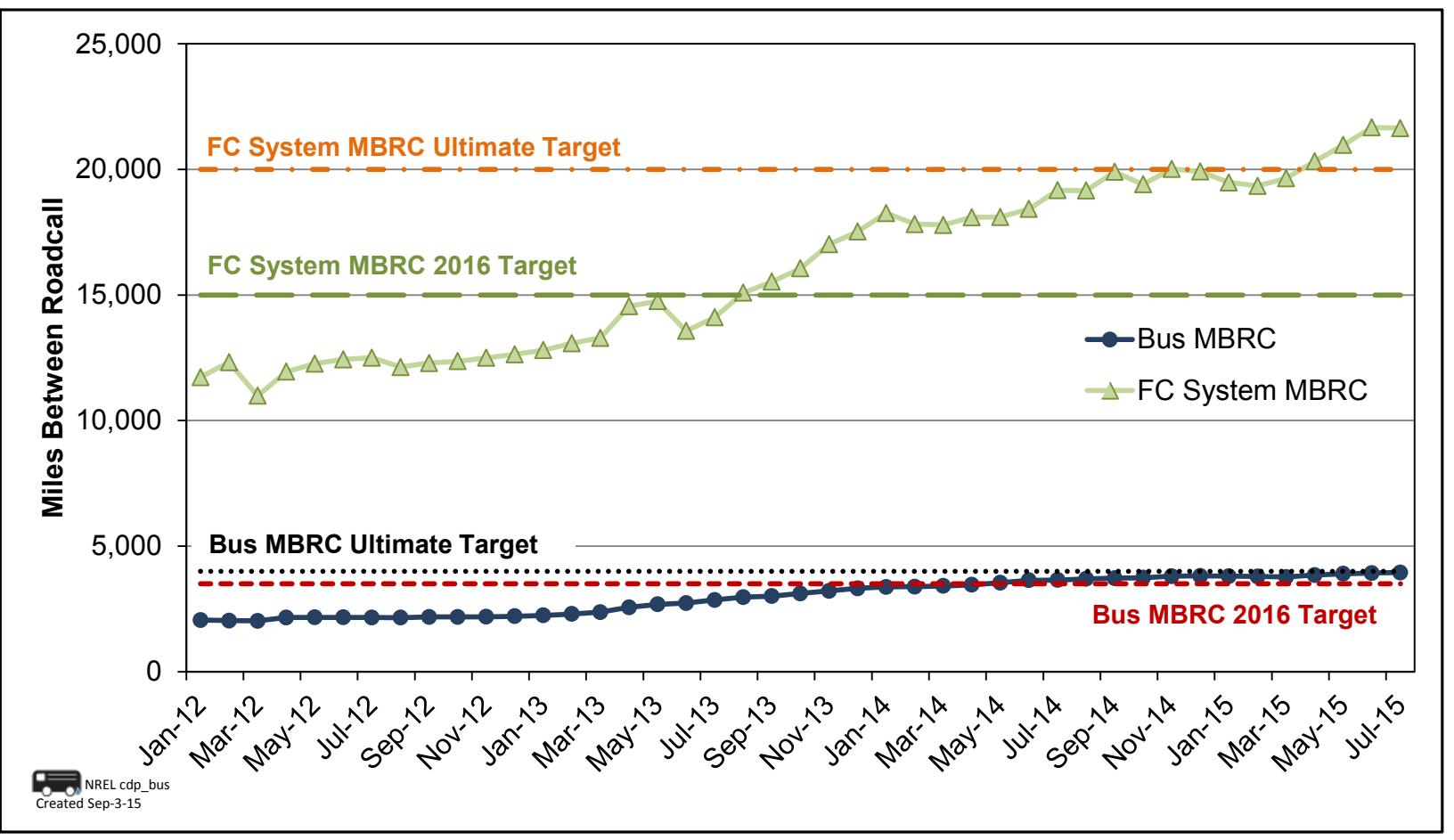

Figure 11. Monthly MBRC for the FCEBs

Table 13 provides the MBRC data for the two demonstrations over four separate data periods covering the last 4 years. (Note that the data shown in Figure 11 are cumulative throughout the entire data period, while Table 13 provides calculated MBRC based on separate data periods. As a result, the data in the table won't necessarily align with the overall trend shown in the figure.) The bus and fuel cell system MBRCs increased from the first data period through the third data period. From the third data period to the fourth data period, both metrics dropped; however, they still meet the DOE/FTA ultimate targets.

Table 13. Summary of MBRC for the Last 4 Years

\begin{tabular}{|l|r|r|r|r|}
\hline & $\begin{array}{c}\text { Data Period 1 } \\
8 / 11-7 / 12\end{array}$ & $\begin{array}{c}\text { Data Period 2 } \\
8 / 12-7 / 13\end{array}$ & $\begin{array}{c}\text { Data Period 3 } \\
8 / 13-7 / 14\end{array}$ & $\begin{array}{c}\text { Data Period 4 } \\
8 / 14-7 / 15\end{array}$ \\
\hline Total miles & 180,721 & 207,760 & 393,124 & 441,026 \\
\hline Bus roadcalls & 96 & 39 & 69 & 93 \\
\hline Bus MBRC & 1,883 & 5,327 & 5,697 & 4,742 \\
\hline Fuel cell system roadcalls & 22 & 12 & 11 & 15 \\
\hline Fuel cell system MBRC & 8,215 & 17,313 & 35,739 & 29,402 \\
\hline
\end{tabular}

\section{Operation Time}

The DOE/FTA target for bus operation is up to 20 hours per day for up to 7 days per week.

SunLine and AC Transit report that the buses have operated as many as 21 hours in a single day. AC Transit's buses are scheduled on route blocks that operate from 3 hours to 21 hours per day. The overall fleet average is just under 12 hours per day. Both agencies report that the buses regularly operate from 5 to 7 days per week. 


\section{Scheduled and Unscheduled Maintenance Cost}

The cost data in the table come from the most recent reports published on the two projects. For AC Transit, the report published in July 2015 covers data through December 2014. For SunLine, the most recent report was published in September 2015 covering data through June 2015. As far as operational costs, most FCEB demonstration project buses are still covered under some level of warranty support from the manufacturers. The AFCBs at SunLine are all still under warranty, so nearly all of the maintenance costs are for labor. Maintenance costs for SunLine are currently $\$ 0.54$ per mile. The buses at AC Transit have reached the end of the original warranty period so parts costs have increased. The agency has negotiated extended contracts with the manufacturers, which has added to the overall maintenance costs. AC Transit's maintenance costs are $\$ 1.33$ per mile with the extended warranty costs included.

\section{Range and Fuel Economy}

Table 14 lists the fuel economy and hydrogen capacity for the FCEBs in both demonstrations as well as an overall average for 40-foot buses. Fuel economy for the FCEBs was similar for the two fleets, with an average of $5.53 \mathrm{mi} / \mathrm{kg}$. The estimated range is calculated based on the fuel economy numbers and useful fuel amount (95\% of the tank's capacity), resulting in an estimated average range for the group of 248 miles.

Table 14. Fuel Economy and Range for the FCEBs

\begin{tabular}{|l|c|c|c|c|}
\hline \multicolumn{1}{|c|}{ ID } & Period & $\begin{array}{c}\text { Fuel Economy } \\
\text { (miles per kg) }\end{array}$ & $\begin{array}{c}\text { Hydrogen Capacity } \\
(\mathrm{kg})\end{array}$ & $\begin{array}{c}\text { Range } \\
\text { (miles) }\end{array}$ \\
\hline ACT ZEBA & $8 / 14-7 / 15$ & 5.96 & 40 & 227 \\
\hline SL AFCB & $8 / 14-7 / 15$ & 5.69 & 50 & 270 \\
\hline Average for 40-ft FCEBs & & $\mathbf{5 . 8 2}$ & & $\mathbf{2 4 8}$ \\
\hline
\end{tabular}

\section{Remaining Challenges}

FCEB performance continues to improve, and new FCEB designs have incorporated the early lessons learned from the first-generation systems. However, there are still challenges to overcome to make the technology commercially viable. This section outlines the ongoing challenges as well as lessons learned from recent issues that occurred over the last year.

Integration/optimization of components-Issues with systems integration and optimization continue to be a challenge for FCEBs. Transit agencies are working closely with the manufacturers to diagnose and address issues to eliminate problems and increase performance. New diagnostic tools have helped, but the agencies are still experiencing problems that are difficult to diagnose and result in extended downtimes.

Bus build process - For FCEBs to be fully commercialized, the fuel cell hybrid propulsion system needs to be an option offered by the bus OEM, as is the case with other propulsion systems. The previous report outlined the progress made by the industry to integrate FCEB manufacturing into the standard process for conventional-technology buses. The development team of BAE Systems, Ballard, and ElDorado National are now fielding orders for a number of AFCBs that are all being built at the ElDorado facility in the standard production line along with conventional-technology buses. To date, six AFCBs have been delivered, and more buses are 
planned that will bring the fleet to a total of 20. Over the last year, New Flyer announced plans to develop a next-generation FCEB for the market. New Flyer already has a battery-electric 40-foot bus in testing at several transit agencies. The FCEB design will be based on the battery-electric version. Both designs are built on New Flyer's Xcelsior platform, which is available with a diesel, $\mathrm{CNG}$, and hybrid electric propulsion system. All of these bus designs will share many components and parts, which will help address a number of past issues experienced by FCEB demonstrations.

Transition of maintenance to transit staff-The transition of knowledge from the manufacturers to the transit staff is essential to commercializing the technology. SunLine's staff has been handling the majority of maintenance tasks for several years. This agency's transition was faster because of its past FCEB experience dating back to 2000. Over the last year, AC Transit has successfully transitioned the maintenance to on-site staff. The agency has trained more personnel to cover the FCEB fleet. The agency has access to the service and maintenance manual, wireless diagnostic tools, and other resources to help troubleshoot issues and perform the repairs on-site. These tools were provided by US Hybrid under its service contract with AC Transit. US Hybrid conducts periodic site visits; however, most of the troubleshooting assistance can be handled remotely. This is a major step toward full commercialization of the technology.

Costs for FCEBs - Maintenance costs for advanced-technology buses typically start low because the buses are under warranty and the manufacturer is taking an active, on-site role in troubleshooting and repair. Costs begin to increase as transit staff takes on more of the maintenance responsibilities and begins the learning curve to understand how to fully maintain the buses. As the staff becomes more proficient, the costs eventually stabilize. The uncertainty for FCEBs at this point in development is how the parts costs will affect the overall maintenance costs over time once all the buses are out of warranty. To help with future planning, transit agencies need to understand future costs as the technology moves into early commercial deployment. Manufacturers need to work on standardization and manufacturing processes to help lower costs for advanced-technology parts and components.

\section{What's Expected for the 2016 Status Report}

This report includes data from four different FCEB bus designs. In the next year, several new demonstrations should begin, and NREL expects to monitor and evaluate those demonstrations with funding from DOE and FTA. The addition of new FCEB designs and demonstration locations is expected to expand this annual assessment report's scope for determining the status of development. NREL plans to produce several new evaluation reports to present data and experiences from each of these sites.

In addition to the current FCEBs, the following demonstrations (with number of buses in parentheses) are expected to be included in next year's assessment report:

- Next-generation AFCB at Massachusetts Bay Transportation Authority in Boston, Massachusetts (1)

- University of California at Irvine (1)

NREL will include additional projects if sufficient data are available for the next report. 


\section{References and Related Reports}

All NREL hydrogen and fuel cell-related evaluation reports can be downloaded from the following website: www.nrel.gov/hydrogen/proj_fc bus eval.html. Some of the most recent reports are included here.

Eudy, L.; Post, M. (2015). American Fuel Cell Bus Project Evaluation: Second Report. NREL/TP-5400-64344. Golden, CO: National Renewable Energy Laboratory.

Eudy, L.; Post, M. (2015). Zero Emission Bay Area (ZEBA) Fuel Cell Bus Demonstration: Fourth Report. NREL/TP-5400-63719. Golden, CO: National Renewable Energy Laboratory.

Eudy, L.; Gikakis, C. (2014). Fuel Cell Buses in U.S. Transit Fleets: Current Status 2014. NREL/TP-5400-62683. Golden, CO: National Renewable Energy Laboratory.

Eudy, L.; Post, M. (2014). BC Transit Fuel Cell Bus Project Evaluation Results: Second Report. NREL/TP-5400-62317. Golden, CO: National Renewable Energy Laboratory. 


\section{Appendix: Summary Statistics}

Table A-1. Technology Readiness Levels for FCEB Commercialization

\begin{tabular}{|c|c|c|c|}
\hline $\begin{array}{l}\text { Relative Level of } \\
\text { Technology } \\
\text { Development }\end{array}$ & $\begin{array}{l}\text { Technology } \\
\text { Readiness } \\
\text { Level }\end{array}$ & TRL Definition & Description \\
\hline $\begin{array}{l}\text { Deployment } \\
\text { (Stage 6) }\end{array}$ & TRL 9 & $\begin{array}{l}\text { Actual system } \\
\text { operated over the full } \\
\text { range of expected } \\
\text { conditions }\end{array}$ & $\begin{array}{l}\text { The technology is in its final form. } \\
\text { Deployment, marketing, and support } \\
\text { begin for the first fully commercial } \\
\text { products. }\end{array}$ \\
\hline \multirow{3}{*}{$\begin{array}{l}\text { Technology } \\
\text { Demonstration/ } \\
\text { Commissioning } \\
\text { (Stage 5) }\end{array}$} & TRL 8 & $\begin{array}{l}\text { Actual system } \\
\text { completed and } \\
\text { qualified through test } \\
\text { and demonstration }\end{array}$ & $\begin{array}{l}\text { The last step in true system development. } \\
\text { Demonstration of a limited production of } \\
50 \text { to } 100 \text { buses at a small number of } \\
\text { locations. Beginning the transition of all } \\
\text { maintenance to transit staff. }\end{array}$ \\
\hline & TRL 7 & $\begin{array}{l}\text { Full-scale validation in } \\
\text { relevant environment }\end{array}$ & $\begin{array}{l}\text { A major step up from TRL } 6 \text { by adding } \\
\text { larger numbers of buses and increasing } \\
\text { the hours of service. Full-scale } \\
\text { demonstration and reliability testing of } 5 \\
\text { to } 10 \text { buses at several locations. } \\
\text { Manufacturers begin to train larger } \\
\text { numbers of transit staff in operation and } \\
\text { maintenance. }\end{array}$ \\
\hline & TRL 6 & $\begin{array}{l}\text { Engineering/pilot-scale } \\
\text { validation in relevant } \\
\text { environment }\end{array}$ & $\begin{array}{l}\text { First tests of prototype buses in actual } \\
\text { transit service. Field testing and design } \\
\text { shakedown of } 1 \text { to } 2 \text { prototypes. } \\
\text { Manufacturers assist in operation and } \\
\text { typically handle all maintenance. Begin to } \\
\text { introduce transit staff to technology. }\end{array}$ \\
\hline \multirow{2}{*}{$\begin{array}{l}\text { Technology } \\
\text { Development } \\
\text { (Stage 3-4) }\end{array}$} & TRL 5 & $\begin{array}{l}\text { Laboratory scale, } \\
\text { similar system } \\
\text { validation in relevant } \\
\text { environment }\end{array}$ & $\begin{array}{l}\text { Integrated system is tested in a laboratory } \\
\text { under simulated conditions based on } \\
\text { early modeling. System is integrated into } \\
\text { an early prototype or mule platform for } \\
\text { some on-road testing. }\end{array}$ \\
\hline & TRL 4 & $\begin{array}{l}\text { Component and } \\
\text { system validation in } \\
\text { laboratory environment }\end{array}$ & $\begin{array}{l}\text { Basic technological components are } \\
\text { integrated into the system and begin } \\
\text { laboratory testing and modeling of } \\
\text { potential duty cycles. }\end{array}$ \\
\hline \multirow[t]{2}{*}{$\begin{array}{l}\text { Research to } \\
\text { Prove Feasibility } \\
\text { (Stage 2) }\end{array}$} & TRL 3 & $\begin{array}{c}\text { Analytical and } \\
\text { experimental critical } \\
\text { function and/or proof } \\
\text { of concept }\end{array}$ & $\begin{array}{l}\text { Active research into components and } \\
\text { system integration needs. Investigate } \\
\text { what requirements might be met with } \\
\text { existing commercial components. }\end{array}$ \\
\hline & \multirow{2}{*}{ TRL 2} & Technology concept & Research technology needed to meet \\
\hline \multirow{2}{*}{$\begin{array}{l}\text { Basic Technology } \\
\text { Research } \\
\text { (Stage 1) }\end{array}$} & & formulated & $\begin{array}{l}\text { market requirements. Defıne strategy for } \\
\text { moving through development stages. }\end{array}$ \\
\hline & TRL 1 & $\begin{array}{c}\text { Basic principles } \\
\text { observed and reported }\end{array}$ & $\begin{array}{l}\text { Scientific research and early development } \\
\text { of FCEB concepts. }\end{array}$ \\
\hline
\end{tabular}




\section{AC Transit ZEBA Demonstration Summary}

Table A-2. AC Transit Data Summary

\begin{tabular}{|c|c|c|c|c|c|c|}
\hline & $\begin{array}{c}\text { ACT } \\
\text { ZEBA } \\
\text { All Data } \\
\end{array}$ & $\begin{array}{c}\text { ACT } \\
\text { ZEBA } \\
\text { Past Year }\end{array}$ & $\begin{array}{c}\text { ACT VH } \\
\text { Diesel } \\
\text { All Data } \\
\end{array}$ & $\begin{array}{c}\text { ACT VH } \\
\text { Diesel } \\
\text { Past Year }\end{array}$ & $\begin{array}{l}\text { ACT Gillig } \\
\text { Diesel } \\
\text { All Data }\end{array}$ & $\begin{array}{c}\text { ACT Gillig } \\
\text { Diesel } \\
\text { Past Year }\end{array}$ \\
\hline Data period & $9 / 11-7 / 15$ & $8 / 14-7 / 15$ & $9 / 11-7 / 15$ & $8 / 14-7 / 15$ & $7 / 13-7 / 14$ & $8 / 14-7 / 15$ \\
\hline Number of buses & 12 & 12 & 4 & 4 & 25 & 12 \\
\hline Number of months & 29 & 12 & 29 & 12 & 25 & 12 \\
\hline Total miles & 884,618 & 360,587 & 193,727 & 193,727 & $1,152,975$ & 509,375 \\
\hline Total fuel cell hours & 102,615 & 40,599 & - & - & - & - \\
\hline Average speed (mph) & 8.5 & 8.9 & - & - & - & - \\
\hline Average miles per month & 2,265 & 2,504 & 4,023 & 4,036 & 4,612 & 4,245 \\
\hline Number of scheduled days & 12,458 & 4,380 & 3,852 & 1,460 & 7,610 & 3,650 \\
\hline Number of days available & 9,087 & 3,283 & 2,996 & 1,141 & 6,665 & 3,270 \\
\hline Availability & $73 \%$ & $75 \%$ & $78 \%$ & $78 \%$ & $88 \%$ & $90 \%$ \\
\hline Fuel economy (miles per kg) & 6.25 & 5.96 & - & - & - & - \\
\hline Fuel economy (miles per DGE) & 7.06 & 6.74 & 3.93 & 3.90 & 4.28 & 4.20 \\
\hline Bus MBRC & 4,379 & 5,007 & 3,647 & 5,381 & 7,205 & 8,486 \\
\hline Propulsion-related MBRC & 7,298 & 8,011 & 7,509 & 8,072 & 17,735 & 17,558 \\
\hline Fuel-cell-system-related MBRC & 21,447 & 32,771 & - & - & - & - \\
\hline Total hydrogen used $(\mathrm{kg})$ & 131,094 & 53,124 & - & - & - & - \\
\hline \multicolumn{7}{|l|}{ SI Units } \\
\hline Total kilometers & $1,423,655$ & 580,309 & 311,773 & 311,773 & $1,855,533$ & 819,760 \\
\hline Average speed (kph) & 13.9 & 14.3 & - & - & - & - \\
\hline Average km per month & 3,645 & 4,030 & 6,475 & 6,495 & 7,422 & 6,831 \\
\hline Fuel consumption $(\mathrm{kg} / 100 \mathrm{~km})$ & 9.94 & 10.42 & - & - & - & - \\
\hline Fuel consumption $(\mathrm{L} / 100 \mathrm{~km})$ & 30.84 & 30.66 & 60.19 & 60.65 & 55.30 & 56.34 \\
\hline $\begin{array}{l}\text { Bus km between roadcalls } \\
\text { (KBRC) }\end{array}$ & 7,047 & 8,057 & 5,869 & 8,660 & 11,595 & 13,657 \\
\hline Propulsion-related KBRC & 11,745 & 12,892 & 12,084 & 12,991 & 28,542 & 28,257 \\
\hline Fuel-cell-system-related KBRC & 34,516 & 52,739 & - & - & - & - \\
\hline
\end{tabular}




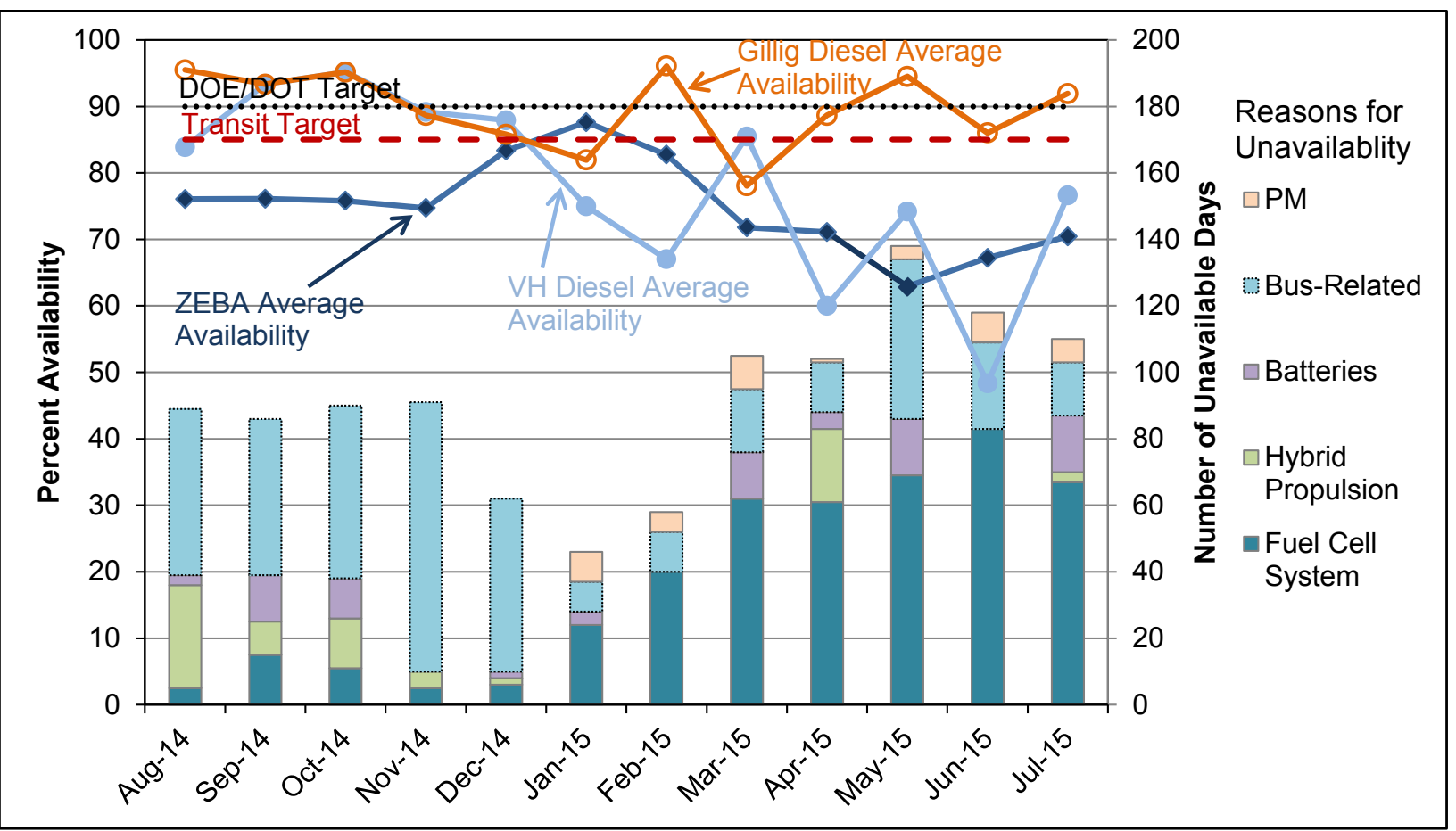

Figure A-1. Monthly availability and number of unavailability days for the ACT ZEBA buses

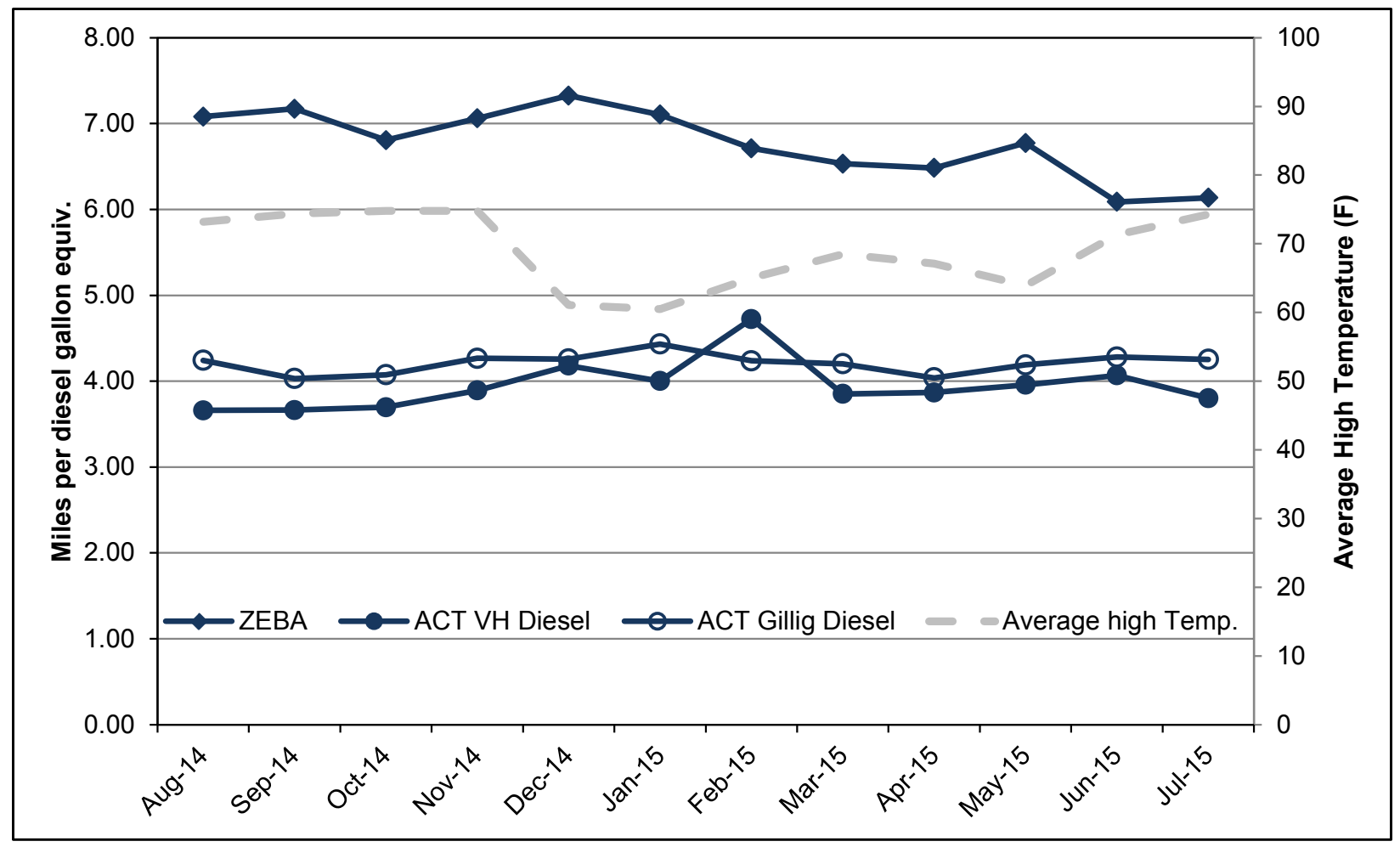

Figure A-2. Monthly fuel economy for the ACT ZEBA and diesel buses 


\section{SunLine AFCB Demonstration Summary}

Table A-3. SunLine Data Summary

\begin{tabular}{|l|c|c|c|c|}
\hline & $\begin{array}{c}\text { SL AFCB } \\
\text { All Data }\end{array}$ & $\begin{array}{c}\text { SL AFCB } \\
\text { Past Year }\end{array}$ & $\begin{array}{c}\text { SL CNG } \\
\text { All Data }\end{array}$ & $\begin{array}{c}\text { SL CNG } \\
\text { Past Year }\end{array}$ \\
\hline Data period & $3 / 12-7 / 15$ & $8 / 14-7 / 15$ & $3 / 12-7 / 15$ & $8 / 14-7 / 15$ \\
\hline Number of buses & 1 & 4 & 5 & 5 \\
\hline Number of months & 41 & 12 & 41 & 12 \\
\hline Total miles & 160,387 & 80,439 & 926,361 & 296,815 \\
\hline Total fuel cell hours & 11,034 & 5,869 & - & - \\
\hline Average speed (mph) & 14.5 & 13.7 & - & - \\
\hline Average miles per month & 3,912 & 2,298 & 4,519 & 4,947 \\
\hline Number of scheduled days & 1,716 & 920 & 5,546 & 1,668 \\
\hline Number of days available & 1,195 & 659 & 4,708 & 1,491 \\
\hline Availability & $70 \%$ & $72 \%$ & $85 \%$ & $89 \%$ \\
\hline Fuel economy (miles per kg or GGE) & 6.03 & 5.69 & 2.86 & 2.94 \\
\hline Fuel economy (miles per DGE) & 6.81 & 6.43 & 3.20 & 3.29 \\
\hline Bus MBRC & 3,730 & 3,830 & 8,822 & 9,894 \\
\hline Propulsion-related MBRC & 6,415 & 5,746 & 26,467 & 24,735 \\
\hline Fuel-cell-system-related MBRC & 17,821 & 20,110 & - & - \\
\hline Total hydrogen used (kg) & 25,805 & 13,474 & - & - \\
\hline SI Units & & & & \\
\hline Total kilometers & 258,118 & 129,454 & $1,490,834$ & 477,677 \\
\hline Average speed (kph) & 23.4 & 22.1 & - & - \\
\hline Average km per month & 6,296 & 3,596 & 7,272 & 7,961 \\
\hline Fuel consumption (kg/100 km) & 10.31 & 10.92 & - & - \\
\hline Fuel consumption (L/100 km) & 33.49 & 34.86 & 73.97 & 71.95 \\
\hline Bus km between roadcalls (KBRC) & 6,003 & 6,164 & 14,198 & 15,923 \\
\hline Propulsion-related KBRC & 10,325 & 9,247 & 42,595 & 39,806 \\
\hline Fuel-cell-system-related KBRC & 28,680 & 32,364 & - & - \\
\hline
\end{tabular}




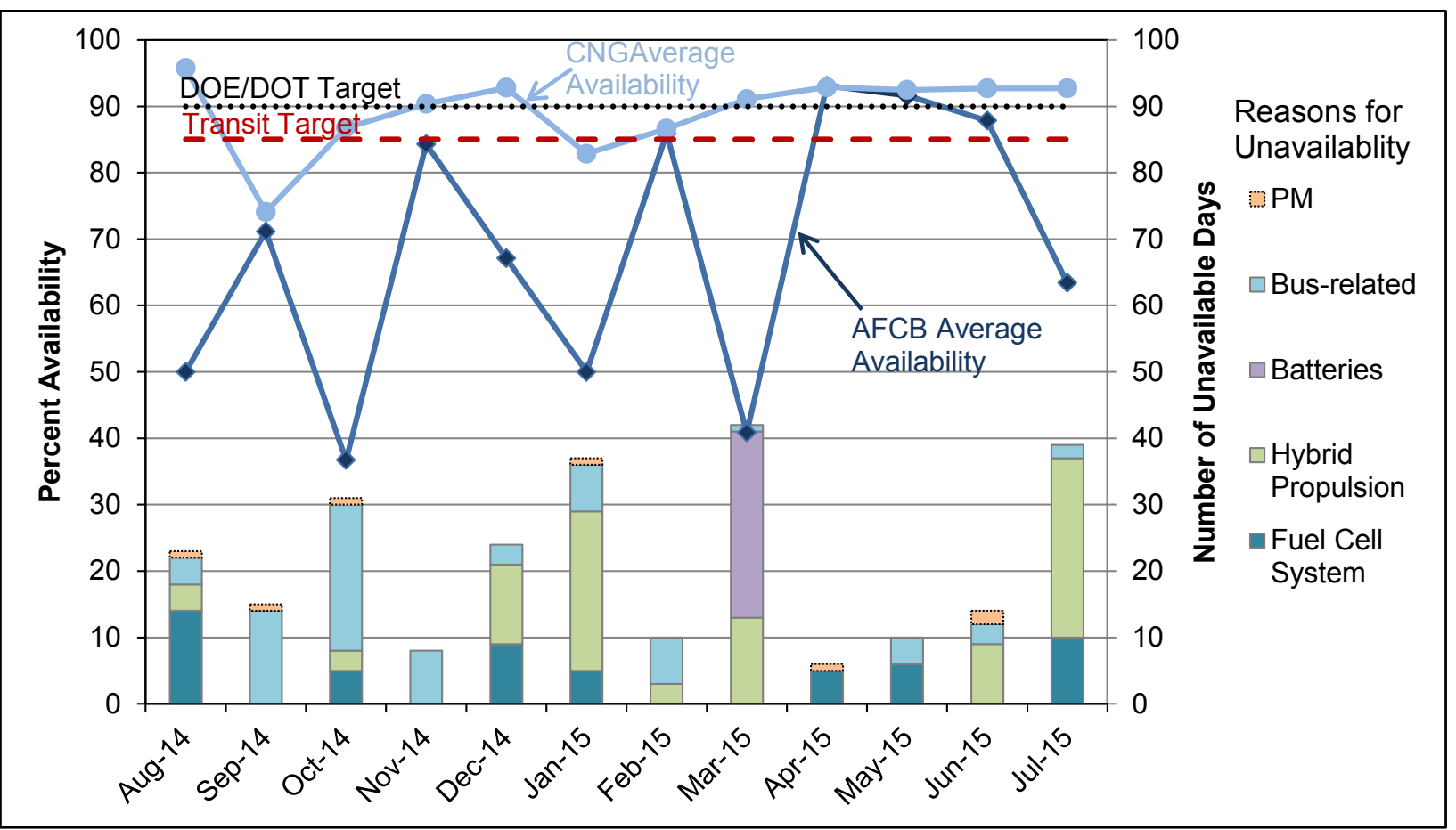

Figure A-3. Monthly availability and number of unavailable days for the SunLine AFCBs

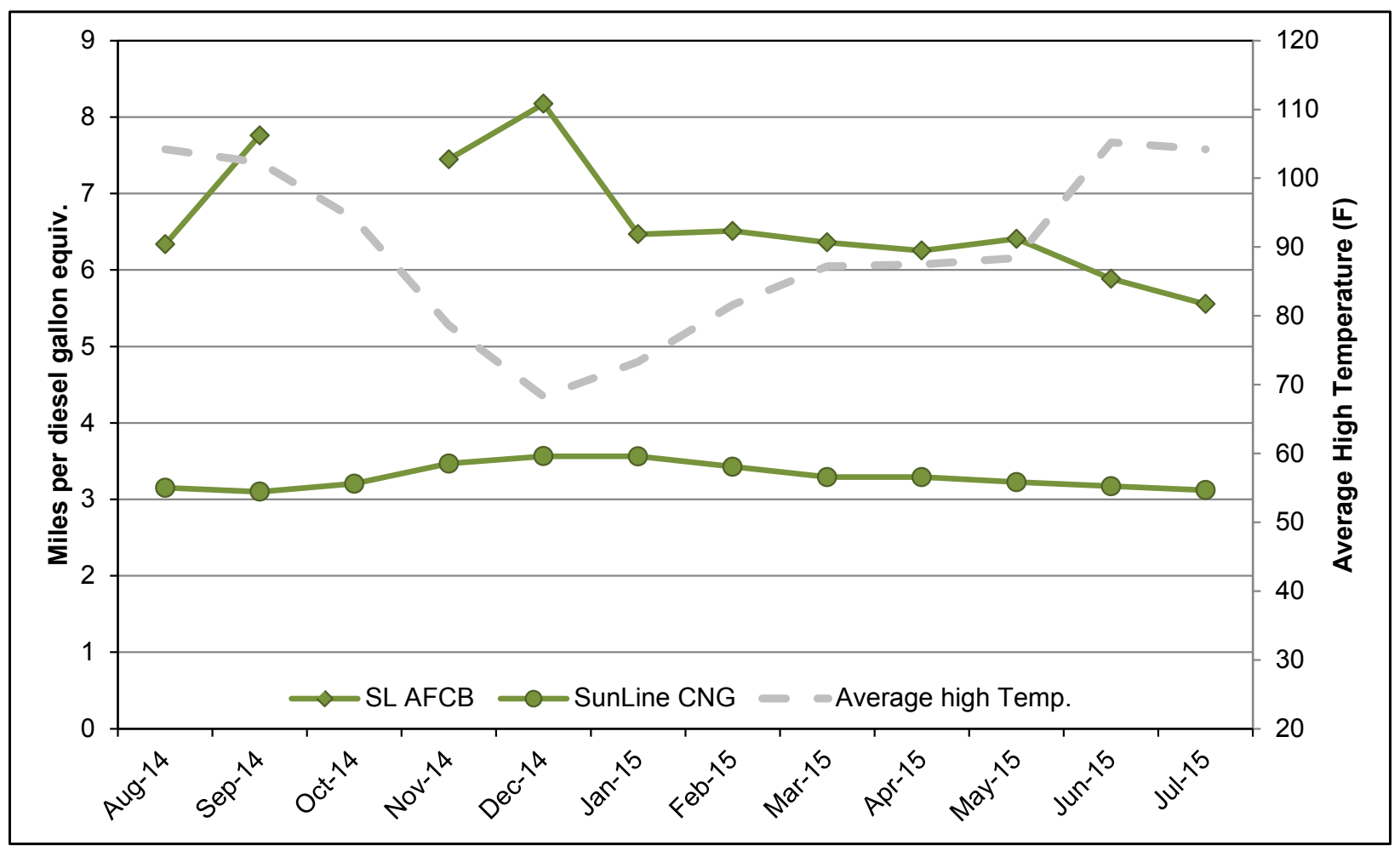

Figure A-4. Monthly fuel economy for the SunLine AFCBs and CNG buses 